\begin{tabular}{|c|l|}
\hline Title & Modeling carbon and silicon cycling in the equatorial Pacific \\
\hline Author(s) & Fujii, Masahiko; Chai, Fei \\
\hline Citation & $\begin{array}{l}\text { Deep Sea Research Part II : Topical Studies in Oceanography, 54(5-7), 496-520 } \\
\text { https://doi.org/40.1016/.dsr2.2006.12.005 }\end{array}$ \\
\hline Issue Date & $2007-03$ \\
\hline Doc URL & http://hdl.handle.net/2115/28236 \\
\hline Type & article (author version) \\
\hline File Information & DSRT54-5-7.pdf \\
\hline
\end{tabular}

Instructions for use 


\section{Modeling carbon and silicon cycling in the equatorial Pacific}

2 Masahiko Fujii $^{1,2, *}$ and Fei Chai ${ }^{1}$

3

$4 \quad{ }^{1}$ School of Marine Sciences, 5706 Aubert Hall, University of Maine, Orono, ME 04469-5706, USA

$5{ }^{2}$ Now at Sustainability Governance Project, Hokkaido University, Sapporo, Hokkaido 060-0809, Japan

$6 \quad$ *Corresponding author. Tel: +81-11-706-4536; Fax: +81-11-706-4534

7 E-mail: mfujii@sgp.hokudai.ac.jp (M. Fujii) 


\section{$1 \quad$ Abstract}

2 The equatorial Pacific is a region of significant particulate inorganic carbon (PIC) and biogenic silica

3 sedimentation, the majority of which is carried out by coccolithophorids and diatoms. We developed an

4 ecosystem model that explicitly includes three phytoplankton functional groups (picoplankton, 5 coccolithophorids, and diatoms), two zooplankton functional groups (microzooplankton and 6 mesozooplankton), nutrients (nitrate $\mathrm{NO}_{3}$, ammonium $\mathrm{NH}_{4}$, and silicate $\mathrm{Si}(\mathrm{OH})_{4}$ ), detritus (particulate 7 organic matter, biogenic silica, and PIC), total alkalinity, total $\mathrm{CO}_{2}$, and partial pressure of $\mathrm{CO}_{2}$ at the 8 surface water $\left(\mathrm{pCO}_{2 \mathrm{sea}}\right)$. The model is capable of reproducing many biogeochemical features for the 9 region, such as high-nutrient low-chlorophyll condition, significant exposure of phytoplankton under 10 grazing controls by zooplankton, and large $\mathrm{CO}_{2}$ release to the atmosphere. The export ratio of PIC to 11 particulate organic carbon (rain ratio) to the deep water was 0.16 , higher than the global-mean values, 12 implying predominant PIC sedimentation in the equatorial Pacific upwelling region. Comparison 13 between calcification and no-calcification model results indicates that when coccolithophorids were 14 present, the community interatctions actually induced more diatom biomass, export fluxes of detritus, 15 and $\mathrm{CO}_{2}$ release to the atmosphere. The model results show remarkable calcification in the subsurface 16 layers, which suggests more field data on calcification processes are needed. Increase of source $(120 \mathrm{~m}$ 17 depth) $\mathrm{Si}(\mathrm{OH})_{4}$ concentration associated with the tropical instability waves lead to a linear increase in 18 biogenic silica export. Higher $\mathrm{Si}(\mathrm{OH})_{4}$ concentration stimulated diatom growth, which caused a 19 decrease in picoplankton because feeding pressure by mesozooplankton switched from picoplankton's 20 grazer, microzooplankton, to the abundant diatoms. Surface coccolithophorid biomass had its 21 maximum at intermediate source $\mathrm{Si}(\mathrm{OH})_{4}$ concentrations as a result of higher grazing pressure on 22 coccolithophorids and higher $\mathrm{NO}_{3}$ regulation on coccolithophorid growth, with lower and higher source $23 \mathrm{Si}(\mathrm{OH})_{4}$ concentrations, respectively. Surface total alkalinity had its minimum and $\mathrm{TCO}_{2}$ had its 
1 maximum at intermediate source $\mathrm{Si}(\mathrm{OH})_{4}$ concentrations. The two effects on $\mathrm{pCO}_{2 \text { sea }}$ resulted in 2 maximum $\mathrm{CO}_{2}$ release to the atmosphere and PIC export to the deep water, with nearby standard source $3 \mathrm{Si}(\mathrm{OH})_{4}$ concentration of $7.5\left[\mathrm{mmolSi} \mathrm{m}^{-3}\right]$. The enhanced changes in biogenic silica export flux than in 4 surface diatom biomass, confirmed by the model sensitivity study, suggests sedimented detritus under 5 the equatorial Pacific upwelling region acts as an amplifier of changes in surface properties. The model 6 results suggest that physical forcings, such as tropical instability waves, Kelvin waves, and La Niña, 7 which are capable of changing $\mathrm{Si}(\mathrm{OH})_{4}$ and iron concentrations in the euphotic zone, significantly 8 affect both carbon and silicon fluxes in the region. 


\section{Introduction}

\section{$2 \quad 1.1$ Calcification in the equatorial Pacific}

Calcifying plankton have a great role in oceanic carbon cycling and global climate change

4 because of particulate inorganic carbon (PIC) shell production resulting in reduced alkalinity and $\mathrm{CO}_{2}$

5 release to the atmosphere, the ballasting effect of carbonate minerals, and the packaging effect of

6 promoting the transfer of organic carbon to the deep sea (e.g. Armstrong et al., 2002; Francois et al., 7 2002).

Previous studies have indicated that the majority $(80 \%)$ of global marine biogenic carbonate

9 precipitation is carried out by coccolithophorids (Deuser and Ross, 1989; Fabry, 1989; Westbroek et al., 10 1989) through their production of PIC coccoliths. Coccolithophorids acts as a significant biotic source

11 of dimethyl sulfide (DMS) for the atmosphere and may influence regional albedo via increased cloud 12 formation (e.g. Bates et al., 1987; Charlson et al., 1987; Brown and Yoder, 1994). The coccolithophorid 13 bloom affects physical environments through changing albedo due to their unique light scattering 14 properties, and biogeochemical processes from lower to higher trophic levels. The progressive increase 15 in atmospheric $\mathrm{CO}_{2}$ concentrations predicted for the next few decades will decrease the production of 16 PIC in the surface ocean (Riebesell et al., 2000; Orr et al., 2005), and thus this response could 17 potentially act as a negative feedback on atmospheric $\mathrm{CO}_{2}$ levels (Iglesias-Rodríguez et al., 2002). Although satellite-based estimates of coccolithophore blooms appear in high-latitude oceans, 19 and the relative paucity of such blooms in the tropics (e.g., Holligan et al., 1983; Brown and Yoder, 20 1994; Brown, 1999; Iglesias-Rodríguez et al., 2002), the equatorial Pacific is known as a region of 21 significant PIC sedimentation (van Andel, 1975), which represents 12-19\% of global PIC production, 22 and is on the same order of magnitude as new production in this region (Chavez and Barber, 1987; 23 Balch and Kilpatrick, 1996). The equatorial Pacific is a largest natural $\mathrm{CO}_{2}$ source to the atmosphere, 
1 and therefore, change in calcification in the region can significantly impact on the global carbon 2 cycling.

3 Calcification in the equatorial Pacific is poorly understood from ecological and 4 biogeochemical perspectives because direct field estimates of calcification are few (Balch and 5 Kilpatrick, 1996). Ecosystem modeling can help us to fill the gaps in observations and interpret 6 observed results. Several ecosystem models have incorporated calcifying plankton as well as carbonate 7 system (e.g. Fujii et al., 2002; Moore et al., 2002; Pätsch et al., 2002; Yamanaka et al., 2004). However,

8 they all assumed a constant composition ratio of coccolithophorids to total phytoplankton or a constant 9 ratio of calcification to net community production. Only very few previous studies have incorporated 10 calcifying plankton in their models as an independent state variable (Pasquer et al., 2005; Buitenhuis et 11 al., 2006).

\section{$13 \quad 1.2$ Silicification in the equatorial Pacific}

The equatorial Pacific upwelling region is known as one of the major high-nutrient, low-chlorophyll (HNLC) regions. This oceanic region is also characterized by permanently lower

$16 \mathrm{Si}(\mathrm{OH})_{4}$ than $\mathrm{NO}_{3}$ concentration. For example, typical source (120m depth) concentration is 7.5

$17\left[\mathrm{mmolSi} \mathrm{m}{ }^{-3}\right]$ for $\mathrm{Si}(\mathrm{OH})_{4}$ and $12.5\left[\mathrm{mmolSi} \mathrm{m}^{-3}\right]$ for $\mathrm{NO}_{3}$, which leads to lower surface $\mathrm{Si}(\mathrm{OH})_{4}$ than

$18 \mathrm{NO}_{3}$ concentration and potential $\mathrm{Si}(\mathrm{OH})_{4}$ limitation on the diatom growth (e.g., $\mathrm{Ku}$ et al., 1995;

19 Dugdale et al., 1995; Dugdale and Wilkerson, 1998). However, field data in this region have shown 20 that the source $\mathrm{Si}(\mathrm{OH})_{4}$ concentration ranges substantially from 3 to 13 [mmolSi m${ }^{-3}$ ] (e.g., Dugdale et 21 al., 2002). This means that the $\mathrm{Si}(\mathrm{OH})_{4}$ limitation on the diatom growth and, therefore, phytoplankton 22 community composition, could change widely in response to the source $\mathrm{Si}(\mathrm{OH})_{4}$ concentration. Recent 23 iron enrichment experiments in the equatorial Pacific have shown that iron as well as $\mathrm{Si}(\mathrm{OH})_{4}$ 
1 concentration are crucial factors determining diatom growth and its biomass accumulation (e.g., Martin

2 et al., 1994; Coale et al., 1996; Price et al., 1994; Sanderson et al., 1995).

Both $\mathrm{Si}(\mathrm{OH})_{4}$ and iron in the surface water are primarily supplied by upwelling from the deep

4 water (e.g., Chavez et al., 1991; Dugdale et al., 2002), although less is known of the distribution of iron,

5 its form, and cycling. The nutrient concentrations change with physical forcing that varies on different

6 time scales from days to years. Several previous studies have investigated biogeochemical responses in

7 the equatorial Pacific to the non steady-state event associated with the passage of the tropical instability

8 waves (TIWs), La Niña and Kelvin waves (e.g., Barber et al., 1996; Foley et al., 1996; Dunne et al.,

9 1999; Dugdale et al., 2002). The passage of the TIWs lifts isopycnals, presumably elevating $\mathrm{Si}(\mathrm{OH})_{4}$

10 and iron concentrations, as well as diatom production in the euphotic zone for a short period (e.g.,

11 Flament et al., 1996: Archer et al., 1997). The passage of Kelvin waves, by contrast, depresses the

12 thermocline (e.g., Kessler and McPhaden, 1995), decreasing inputs of iron to the euphotic zone.

Although the concept of non steady-state is important in understanding equatorial

14 biogeochemical cycles (e.g., Dunne et al., 1999), the total impact of the TIWs and Kelvin waves and

15 their frequency still remains uncertain mainly due to a paucity of field data. In parallel, several

16 modeling studies have examined the biological responses to enhanced nutrients by the TIWs. Using a

17 ten-compartment ecosystem model that fully incorporates silicon cycling, and representing iron

18 enrichment by changing two photosynthetic parameters of the diatoms, Chai et al. (2002) reproduced

19 several ecological behaviors similar to those observed during the second mesoscale iron enrichment

20 experiment (IronExII; at $3.5^{\circ} \mathrm{S}, 104^{\circ} \mathrm{W}$ ). These behaviors included a rapid increase in diatom growth

21 and biomass, termination of the iron-induced diatom bloom due to exhaustion of available iron and

$22 \mathrm{Si}(\mathrm{OH})_{4}$, and increased mesozooplankton population as a grazer on diatoms. Using the same ecosystem

23 model, Dugdale et al. (2002) suggested that the stability of the equatorial system with its narrow range 
1 of biological and chemical variables is conferred by the action of diatoms providing food for

2 mesozooplankton, whose grazing also depletes picoplankton. They also suggested that diatoms increase

3 while picoplankton population and $\mathrm{NO}_{3}$ consumption decrease with source $\mathrm{Si}(\mathrm{OH})_{4}$ increases. As a

4 result, a maximum surface total carbon dioxide $\left(\mathrm{TCO}_{2}\right)$ and increased $\mathrm{CO}_{2}$ flux to the atmosphere

5 appear at intermediate source $\mathrm{Si}(\mathrm{OH})_{4}$ concentrations.

6

\section{1.3. Objective of this study}

To elucidate factors that affect calcification and PIC sedimentation in the equatorial Pacific,

9 we propose to address the roles of coccolithophorids and other phytoplankton and zooplankton groups

10 that affect coccolithophorids. We develop and use an ecosystem model incorporating coccolithophorids,

11 PIC, and total alkalinity. The model performance is tested by applying the model to the equatorial

12 Pacific upwelling region. Model sensitivity analysis to biogeochemical parameters (Experiment 1) is

13 conducted to understand dominant biological processes in the newly-developed ecosystem model.

To examine responses of the biogeochemistry in the equatorial Pacific to changes in $\operatorname{Si}(\mathrm{OH})_{4}$

15 and iron concentrations in the euphotic zone induced by the TIWs, we conduct a model sensitivity

16 study (Experiment 2). In Experiment 2, we investigate model sensitivity to the source (120m depth)

$17 \mathrm{Si}(\mathrm{OH})_{4}$ concentrations under the steady-state conditions. We compare all the model results to those

18 with no-calcification model simulation, as well as the JGOFS EqPac field data. 


\section{2. Experimental design}

\section{2.1. Model description}

We added three prognostic variables, namely calcifying phytoplankton (coccolithophorids, or

4 P3), total alkalinity (TAlk), and particulate inorganic carbon (PIC) (Fig. 1), as well as the other

5 phytoplankton functional groups (picoplankton (P1) and diatoms (P2)), zooplankton (microzooplankton

6 (Z1) and mesozooplankton (Z2)), nutrients $\left(\mathrm{NO}_{3}, \mathrm{NH}_{4}\right.$ and $\left.\mathrm{Si}(\mathrm{OH})_{4}\right)$, detritus (particulate organic

7 nitrogen and carbon (PON and POC) and biogenic silica $\left.\left(\mathrm{bSiO}_{2}\right)\right)$, total $\mathrm{CO}_{2}\left(\mathrm{TCO}_{2}\right)$, and partial

8 pressure of $\mathrm{CO}_{2}$ in the surface water $\left(\mathrm{pCO}_{2 \text { sea }}\right)$ which were embedded in a 1-D marine ecosystem model

9 (Chai et al., 2002). The phytoplankton and zooplankton were separated by their functional groups, not

10 only by their size but also according to their growth and vulnerability to grazing. All the phytoplankton

11 take up $\mathrm{NO}_{3}, \mathrm{NH}_{4}$, and $\mathrm{TCO}_{2}$ by the photosynthesis. The diatoms also utilize $\mathrm{Si}(\mathrm{OH})_{4}$ for their

12 silicification process and the coccolithophorids take up TAlk as well as $\mathrm{TCO}_{2}$ for its calcification

13 process. The microzooplankton graze on picoplankton. The mesozooplankton feed on diatoms,

14 coccolithophorids, microzooplankton and PON. The explicit representation of Talk and $\mathrm{TCO}_{2}$ in the

15 model allows us to calculate $\mathrm{pCO}_{2 \text { sea }}$ and the air-sea $\mathrm{CO}_{2}$ flux. The phytoplankton carbon-chlorophyll-a

16 ratio by weight was fixed to 50. The governing equations and formulations of biogeochemical

17 processes were denoted in Appendix.

The model was applied to $5^{\circ} \mathrm{S}-5^{\circ} \mathrm{N}, 90-180^{\circ} \mathrm{W}$ (the "Wyrtki Box", Wyrtki, 1981; Chai et al.,

19 2002). The physical forcing is the same, and most of the biogeochemical parameter values are the same

20 as Chai et al. (2002) (Table 1). The parameter values were obtained to reproduce the

21 temporally-averaged observed constituents such as nutrient concentrations and new production in the

22 euphotic layer (Chai et al., 1996), which varied between El Niño and non-El Niño periods (e.g.

23 McCarthy et al., 1996). Steady-state results obtained by running the model up to 1000 days with the 
1 constant vertical velocity and diffusivity were used.

\subsection{Data description}

Datasets were used to tune the biological parameters and to compare with model outputs.

5 Datasets used in this study are as follows: the U.S. JGOFS EqPac observations in February-March

6 (Survey I; TT007), March-April (Time series I; TT008), August-September (Survey II; TT011) and

7 October (Time series II; TT012) of 1992 (e.g. Murray et al., 1995, 1996 and 1997; Balch and Kilpatrick,

8 1996; Barber et al., 1996); the France JGOFS fluxes in the Pacific transect (FLUPAC) in October of

91994 (Le Borgne et al., 1995 ; Rodier and Le Borgne, 1997); the Oligotrophie en Pacifique (OLIPAC)

10 in November 1994 (Rainbault et al.,1999); the U.S. Zonal Flux transect (Zonal Flux) in April-May of

111996 (Dunne et al., 1999); the Etude du Broutage en Zone Equatoriale (EBENE) cruise in

12 October-November of 1996 (Le Borgne et al., 1998; Leynaert et al., 2001); the World Ocean Database

132001 (WOD01; Conkright et al., 2002); the IronExII field data (Coale et al., 1996; Landry et al., 2000).

\subsection{Comparison between calcification and no-calcification model simulations}

To elucidate effects of newly-introduced coccolithophorids and its calcification processes on

17 the entire biogeochemistry in the equatorial Pacific upwelling region, we compared model results with

18 and without components and processes that were relevant to the calcification. In the no-calcification

19 model simulation, we have excluded state variables of coccolithophorids and PIC. The no-calcification

20 model structure was identical to that in Chai et al. (2002) and Dugdale et al. (2002). Small differences

21 in the model results from the previous studies were attributed to different values in several

22 biogeochemical parameters between the studies (Table 1; Chai et al. 2002). 
$8\left[\mathrm{mmolN} \mathrm{m}^{-3}\right]$ for picoplankton, $0.06\left[\mathrm{mmolN} \mathrm{m} \mathrm{m}^{-3}\right]$ for diatoms, and $0.03\left[\mathrm{mmolN} \mathrm{m}^{-3}\right]$ for

9 coccolithophorids (Table 2). The percentage of diatoms in the total modeled phytoplankton biomass

10 was $24 \%$, which was slightly higher but was consistent with the observed range of 5-20\% (Bidigare 11 and Ondrusek, 1996).

\section{Results}

\subsection{Calcification model}

The modeling results reasonably reproduced the measured vertical features in the biogeochemistry in the equatorial Pacific, such as consistently higher $\mathrm{NO}_{3}$ than $\mathrm{Si}(\mathrm{OH})_{4}$ concentration (solid line in Fig. 2 (d), (f)). The modeled picoplankton (P1) was more abundant than diatoms (P2) and coccolithophorids (P3) (solid lines in Fig. 2 (a)), which has been suggested from the observations (Bidigare and Ondrusek, 1996). The modeled vertically-averaged phytoplankton abundance was 0.15

The modeled vertically-averaged biomass was $0.13\left[\mathrm{mmolN} \mathrm{m}^{-3}\right]$ for microzooplankton $(\mathrm{Z} 1)$ and $0.28\left[\mathrm{mmolN} \mathrm{m}^{-3}\right.$ ] for mesozooplankton (Z2) (Table 2), indicating that mesozooplankton was more plentiful than the other plankton, and therefore, possibly high grazing or predation pressure by mesozooplankton in the equatorial Pacific upwelling region. The abundance in the modeled zooplankton rapidly decreased with depth (solid lines in Fig. 2 (c)), as a result of their grazing and predation being dependent on biomass of their prey (Appendix A.2).

The modeled $\mathrm{NO}_{3}$ and $\mathrm{Si}(\mathrm{OH})_{4}$ increased with depth (solid line in Fig. 2 (d), (f)), resulting from nutrient uptake by phytoplankton near the surface and remineralization of $\mathrm{PON}$ and $\mathrm{bSiO}_{2}$ below the depth. At $120 \mathrm{~m}, \mathrm{Si}(\mathrm{OH})_{4}$ concentration was 7.5 [mmolSi m$\left.{ }^{-3}\right]$, whereas $\mathrm{NO}_{3}$ concentration was 12.0

$21\left[\mathrm{mmolN} \mathrm{m}^{-3}\right]$, and these values are close to the observed climatological data, respectively (e.g. Levitus 2 et al., 1993; Murray et al., 1995; Chai et al., 2002; Dugdale et al., 2002). The surface concentration was $6.1\left[\mathrm{mmolN} \mathrm{m}^{-3}\right]$ in $\mathrm{NO}_{3}$ and $3.1\left[\mathrm{mmolSi} \mathrm{m}^{-3}\right]$ in $\mathrm{Si}(\mathrm{OH})_{4}$. The model captured the observed 
1 subsurface maximum of $\mathrm{NH}_{4}$ concentration (solid line in Fig. 2 (e); Murray et al., 1995). The

2 subsurface $\mathrm{NH}_{4}$ maximum is due to higher uptake rate of $\mathrm{NH}_{4}$ near the surface mainly by picoplankton

3 which has relatively smaller half-saturation constant for $\mathrm{NH}_{4}$ uptake $\left(0.1\left[\mathrm{mmolN} \mathrm{m}{ }^{-3}\right]\right)$ than the other

4 phytoplankton has $\left(1.0\left[\mathrm{mmolN} \mathrm{m}^{-3}\right]\right)($ Table 1$)$. The modeled $\mathrm{TCO}_{2}$ had similar vertical profile as of nutrients, increasing with depth (solid line

6 in Fig. 2 (h)), as a result of $\mathrm{TCO}_{2}$ uptake by phytoplankton growth and calcification by 7 coccolithophorids in the upper layer and decomposition of POC and PIC in the lower layer. The TAlk 8 was only changed by the calcification process, i.e. shell formation by coccolithophorids in the upper 9 layer and dissolution of PIC in the lower layer, so the vertical change was smaller in TAlk than in $\mathrm{TCO}_{2}$ 10 (solid lines in Fig. $2(\mathrm{~g})$, (h)). The $\mathrm{pCO}_{2 \text { sea }}$ depends on TAlk as well as the temperature, salinity and $11 \mathrm{TCO}_{2}$ in the surface water, so it could be estimated more precisely than with previous models which 12 did not explicitly incorporate change of TAlk (e.g. Chai et al., 2002). The $\mathrm{pCO}_{2 \mathrm{sea}}$ was 401 [ $\left.\mu \mathrm{atm}\right]$ 13 (Table 3), close to the observed values (e.g. Feely et al., 1997). The $\mathrm{pCO}_{2 \text { sea }}$ was much higher than the 14 partial pressure of $\mathrm{CO}_{2}$ in the atmosphere of 357 [ $\left.\mu \mathrm{atm}\right]$ (Appendix A.1; Chai et al., 2002), suggesting 15 the equatorial Pacific upwelling region as a large $\mathrm{CO}_{2}$ source to the atmosphere, as the observed. The modeled net community production was obtained by multiplying the nitrogen changes in

17 the water column by the Redfield stoichiometric ratio of 6.625 (Table 1). The modeled vertical profile 18 of net community production reproduced well the observations (Fig. 3 (a)), implying that fixing a 19 phytoplankton carbon:nitrogen ratio is a good assumption in this region. The modeled calcification in 20 the euphotic zone (Fig. 3 (b)) was lower than the field data during EqPac Survey II (TT011; in August 21 1992) in which the measured calcification was considered to be higher than the normal conditions 22 (Balch and Kilpatrick, 1996). The modeled column-integrated ratio of calcification to net community 23 production was 0.06 , lies on a lower end of the observed range from 0.03 to 0.12 during EqPac Survey 
1 II (Balch and Kilpatrick, 1996). A higher ratio of the calcification to the net community production

2 could be reproduced by changing a few model parameter values which are relevant to

3 coccolithophorids, such as the maximum specific growth rate of coccolithophorids $\left(\mu 3_{\max }\right)$ and the

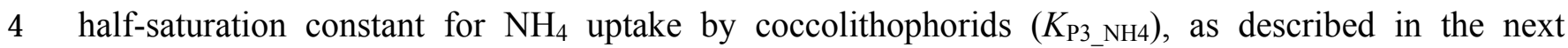

5 subsection.

The modeled $\mathrm{bSiO}_{2}$ production with depth showed a pattern similar to that of the net

7 community production although the modeled $\mathrm{bSiO}_{2}$ production decreased more rapidly with depth (Fig.

83 (a), (c)). The modeled vertical profile reproduced the field data (Leynaert et al., 2001), but the model

9 overestimated the field results in the lower layer. Unlike the calcification data, the $\mathrm{bSiO}_{2}$ data were

10 collected during the EBENE cruise in October-November 1996, which took place during a "neutral

11 scenario" between El Niño and La Niña (Leynaert et al., 2001). Therefore, the $\mathrm{bSiO}_{2}$ data can be

12 considered to be normal, and the model-data misfit was probably caused by other biological factors

13 such as a vertical change in the diatom Si:N uptake ratio that was not considered in the present model.

The modeled $\mathrm{bSiO}_{2}: \mathrm{POC}$ production ratio remarkably decreased with depth, from 0.03 at the surface to nearly zero at $120 \mathrm{~m}$ depth, following the rapid decrease in diatom biomass with depth (solid

16 line in Fig. 2 (a)) as observed (e.g. Barber et al., 1996). The modeled PIC:POC production ratio, by

17 contrast, was relatively similar with depth but had its maximum of 0.07 around 50m depth (Fig. 3 (d)).

18 The increased dominancy of coccolithophorids in the subsurface layers resulted from its strategy to

19 seek for $\mathrm{NH}_{4}$ which was rapidly consumed by picoplankton in the surface water (solid line in Fig. 2 (e)).

20 This implies that the calcification in the subsurface layers, which cannot be detected by satellite

21 observations, plays a considerable role in significant PIC sedimentation in the equatorial Pacific.

The modeled export flux of PON, POC, $\mathrm{bSiO}_{2}$, and PIC at $120 \mathrm{~m}$ depth was $0.58\left[\mathrm{mmolN} \mathrm{m}^{-2}\right.$ 
1 (Table 4). All the export fluxes of PON, POC and $\mathrm{bSiO}_{2}$ lie within the observed wide ranges of

$2 \quad 0.38-4.65\left[\mathrm{mmolN} \mathrm{m}^{-2}\right.$ day $\left.^{-1}\right], 0.6-20\left[\mathrm{mmolC} \mathrm{m}^{-2}\right.$ day $\left.^{-1}\right]$ and 0.05-3.9 $\left[\mathrm{mmolSi} \mathrm{m}^{-2}\right.$ day $\left.^{-1}\right]$, respectively.

3 The PIC:POC export ratio (rain ratio) in the equatorial Pacific upwelling region was 0.16 in this study

4 (Table 4). This is relatively higher than recent estimates of 0.05-0.08 for the global-mean rain ratio (e.g.

5 Yamanaka and Tajika, 1996; Najjar and Orr, 1998; Milliman et al., 1999; Sarmiento et al., 2002; Fujii

6 et al., 2005a), implying notable PIC export in the equatorial Pacific compared to the global ocean, as

7 reported by Balch and Kilpatrick (1996).

8 The modeled $\mathrm{bSiO}_{2}: \mathrm{PON}$ export ratio was 2.52 (Table 4), which lies between the maximum

9 ratio of nearly 4 obtained by Dugdale et al. (2002) and other sediment trap data of 0.10-1.25 (Dunne et

10 al., 1999). Recent data show that bacterial protease activity accelerates the dissolution of $\mathrm{bSiO}_{2}$ in the

11 euphotic zone (Bidle and Azam, 1999), and that such process is strongly dependent on water

12 temperature (Bidle et al., 2002, 2003). Other previous studies suggested that the dissolution of bSiO${ }_{2}$ is

13 correlated to the percentage of dead diatoms, and that other factors controlling $\mathrm{bSiO}_{2}$ dissolution rate

14 besides water temperature, such as differences in organic coatings that protect against $\mathrm{bSiO}_{2}$ dissolution

15 between live and dead diatoms, are probably required (Beucher et al., 2004; Fujii and Chai, 2005).

16 These factors, which were not taken into account in the present model, probably contributed to the

17 large spatial and temporal variation among the observed $\mathrm{bSiO}_{2}: \mathrm{PON}$ export ratios and to regard

18 sedimented biogenic silica under the equatorial upwelling area as anplifier of changes in surface

19 properties (Dugdale et al., 2002).

20

\section{$21 \quad 3.2$. Comparison with no-calcification model results}

We compared the standard model experimental results with and without coccolithophorids and

23 its calcification processes (hereafter calcification and no-calcification model simulation, respectively). 
1 The no-calcification model results were obtained by eliminating all the parameters that are associated

2 with coccolithophorids and its calcification processes and by modifying the grazing preference by

3 mesozooplankton properly (Table 1).

4 The model results showed that surface diatom biomass was less than half in the 5 no-calcification model simulation, although the diatom specific growth rate (diatom growth rate

6 divided by its biomass) was $23 \%$ higher due to higher $\mathrm{Si}(\mathrm{OH})_{4}$ concentration (Table 3; Fig. 2 (a), (f)).

7 This results from absence of grazing pathway by mesozooplankton on coccolithophorids and

8 subsequently higher grazing pressure on diatoms by mesozooplankton (by a factor of 1.3 in terms of

9 the specific grazing rate, grazing rate divided by prey's biomass) in the no-calcification model

10 simulation (Table 3). The absence of coccolithophorids in the no-calcification model simulation yielded

11 enhancement of the other feeding pathways by mesozooplankton, namely predation on

12 microzooplankton and grazing on PON as well, by a factor of 1.6 and 1.8, respectively (Table 3). As a

13 result, mesozooplankton biomass was $26 \%$ higher in the no-calcification model simulation (Table 3;

14 Fig. 2 (c)). The substantially enhanced predation on microzooplankton by mesozooplankton in the 15 no-calcification model simulation slightly lowered grazing pressure on picoplankton by

16 microzooplankton, which lead to $33 \%$ higher picoplankton biomass regardless of its lower specific

17 growth rate due to lower $\mathrm{NH}_{4}$ and $\mathrm{NO}_{3}$ concentrations than in the calcification model simulation (Table

18 3; Fig. 2 (a), (d), (e)).

Compared to the change in each phytoplankton biomass between the calcification and

20 no-calcification model simulations, the total phytoplankton biomass in the surface water was similar

21 between the two models, because the absence of coccolithophorids and the lower diatom biomass in the

22 no-calcification model simulation were partly compensated by the higher picoplankton biomass (Table

23 3; Fig. 2 (a), (b)). The export flux of PON or POC, which is generated from phytoplankton mortality 
1 and fecal pullet, was similar as well (changing only by $12 \%$; Table 4). On the other hand, the $\mathrm{bSiO}_{2}$

2 export was lower in the no-calcification model simulation by $49 \%$ (Table 4 ). Same as the relationship 3 between the surface $\mathrm{NO}_{3}$ and $\mathrm{Si}(\mathrm{OH})_{4}$, the change was relatively smaller in surface $\mathrm{TCO}_{2}$ than in TAlk 4 between the two models (Table 3; Fig. 2 (g), (h)). The higher TAlk and lower $\mathrm{TCO}_{2}$ causes lower $5 \mathrm{pCO}_{2 \text { sea }}$ in the no-calcification model simulation by $47 \mu$ atm (Table 3), which was primarily affected by 6 the increase in TAlk. 


\section{4. Discussion}

\subsection{Sensitivity to biogeochemical parameters (Experiment 1)}

We tested model sensitivity to each biogeochemical parameter by changing the parameter

4 value from 0.5 to 1.5 times the standard value (Table 1). We found the model results, i.e., surface

5 plankton abundance, concentrations of nutrients, TAlk and $\mathrm{TCO}_{2}, \mathrm{pCO}_{2 \text { sea }}$, and export fluxes of PON,

$6 \mathrm{bSiO}_{2}$ and PIC, were especially sensitive to changes in six model parameters relevant to grazing or

7 predation by zooplankton, namely the maximum grazing and/or predation rates by zooplankton $\left(G 1_{\max }\right.$

8 and $\left.G 2_{\max }\right)$, the half-saturation constants for zooplankton ingestion $\left(K 1_{\mathrm{gr}}\right.$ and $\left.K 2_{\mathrm{gr}}\right)$, the

9 mesozooplankton excretion rate to $\mathrm{NH}_{4}\left(\mathrm{reg}_{2}\right)$, and the mesozooplankton specific mortality rate $\left(\gamma_{2}\right)$

10 (Table 5). This suggests that the phytoplankton in the equatorial Pacific upwelling area is universally

11 and severely exposed under the top-down (grazing) control by zooplankton. This is consistent with the

12 observed results that grazing has been invoked as the control on loss rates (e.g. Walsh, 1976; Landry et

13 al., 1997; Dugdale et al., 2002).

The maximum grazing or predation rate by mesozooplankton $\left(G 2_{\max }\right)$ was the most significant

15 parameter to determine surface diatoms, coccolithophorids, $\mathrm{Si}(\mathrm{OH})_{4}, \mathrm{TAlk}, \mathrm{TCO}_{2}$, and export fluxes of

16 PON and PIC (Table 5; Fig. 4). The lower $G 2_{\max }$ caused lower grazing pressure on diatoms and

17 coccolithophorids and subsequently higher diatom and coccolithophorid biomass, which lead to higher

18 export fluxes of POC, $\mathrm{bSiO}_{2}$ and PIC, and lower TAlk and $\mathrm{TCO}_{2}$ (Fig. 4 (a), (b), (c), (d), (f)). The

19 simultaneous decrease in TAlk and $\mathrm{TCO}_{2}\left(238\left[\mathrm{mmol} \mathrm{m}^{-3}\right]\right.$ and $149\left[\mathrm{mmolC} \mathrm{m}^{-3}\right]$, respectively $)$ with

$20 G 2_{\max }$ decrease compensated each other in terms of $\mathrm{pCO}_{2 \text { sea }}$ change, which yielded $\mathrm{pCO}_{2 \text { sea }}$ decrease of

21137 [ $\mu \mathrm{atm}]$ (Fig. 4 (e)), significant but relatively small compared to the individual changes in TAlk and $22 \mathrm{TCO}_{2}$.

The maximum grazing rate on picoplankton by microzooplankton $\left(G 1_{\max }\right)$ was the most 
1 effective parameter in determining surface picoplankton biomass and $\mathrm{NO}_{3}$ (Table 5). Two

2 phytoplankton-related parameters (the initial slope of P-I curve $(\alpha)$ and the maximum specific growth

3 rate of picoplankton $\left(\mu_{1 \max }\right)$ ) also controlled the model results, but less broadly than the

4 zooplankton-related parameters above did (Table 5). The surface TAlk and $\mathrm{TCO}_{2}$ varied by 21-45

$5 \quad\left[\mathrm{mmol} \mathrm{m}^{-3}\right]$ and $53-81\left[\mathrm{mmolC} \mathrm{m}^{-3}\right]$, respectively, by changing one of the three parameter values (Table

6 5; Fig. 5 (a), (b)). These changes were relatively small compared those brought by $G 2_{\max }$ change of 238

$7\left[\mathrm{mmol} \mathrm{m}^{-3}\right]$ and $149\left[\mathrm{mmolC} \mathrm{m} \mathrm{m}^{-3}\right]$, respectively. However, surface TAlk and $\mathrm{TCO}_{2}$ changed in a

8 different way with parameter values, i.e., surface TAlk increased and $\mathrm{TCO}_{2}$ decreased with parameter

9 values of $\alpha$ and $\mu_{1 \max }$, and vice versa for $G 1_{\max }$. This is the reason why the $\mathrm{pCO}_{2 \text { sea }}$ change by changing

10 these parameter values was relatively large $(184,147$ and 160 [ $\mu \mathrm{atm}]$ for $\alpha, \mu_{1 \max }$ and $G 1_{\max }$,

11 respectively; Table 5; Fig. 5 (c)).

12 The surface coccolithophorid biomass and the export PIC flux at 120m depth were sensitive to 13 many parameters (Table 5). For example, a few parameters like the maximum specific growth rates of 14 coccolithophorids $\left(\mu 3_{\max }\right)$ and the half-saturation constant for $\mathrm{NH}_{4}$ uptake by coccolithophorids $15\left(K_{\mathrm{P} 3 \_\mathrm{NH} 4}\right)$ specialized to control the two model state variables. This means that the modeled 16 coccolithophorids and PIC could change in a sensitive and complicated way with a narrow range of the 17 parameter values. For more realistic simulation of carbon cycling in this region, we need further field 18 data, especially for vertical profiles of POC, PIC, coccolithophorid biomass and its composition ratio 19 for the phytoplankton community.

The model sensitivity study to the five parameters of $\alpha, \mu 1_{\max }, \mu 3_{\max }, G 1_{\max }$ and $G 2_{\max }$ revealed 21 that the $\mathrm{bSiO}_{2}: \mathrm{PON}$ export ratio and the PIC:POC export ratio (rain ratio) at $120 \mathrm{~m}$ depth could vary by $220.40-2.83$ and $0.00-0.56$, respectively (Fig. 6). Considering that the observation-based estimates of the 23 global rain ratio vary from 0.05 to 0.25 (e.g. Fujii et al., 2005a) and excluding the model results in 
1 which the rain ratio was out of the range (Fig. 6 (b)), we obtained a range of 1.51-2.75 for the

$2 \quad \mathrm{bSiO}_{2}: \mathrm{PON}$ export ratio (Fig. 6 (a)).

3

4 4.2. Sensitivity to source $\mathrm{Si}(\mathrm{OH})_{4}$ concentration (Experiment 2)

Experiment 2 is similar to the experiment conducted by Dugdale et al. (2002), i.e., the source

6 (120m depth) $\mathrm{Si}(\mathrm{OH})_{4}$ concentration was varied from 3.0-15.0 [mmolSi $\left.\mathrm{m}^{-3}\right]$, corresponding to the full

7 range of JGOFS equatorial values of 3-13 [mmolSi m$\left.{ }^{-3}\right]$ (Dugdale et al., 2002). The $\mathrm{NO}_{3}$ concentration

8 at $120 \mathrm{~m}$ depth was held constant at $12.0\left[\mathrm{mmolN} \mathrm{m}^{-3}\right]$.

9

\subsubsection{Calcification model simulation}

With source $\left(120 \mathrm{~m}\right.$ depth) $\mathrm{Si}(\mathrm{OH})_{4}$ concentration increases, surface $\mathrm{Si}(\mathrm{OH})_{4}$ concentration

12 increased linearly from 1.8 to 6.6 [mmolSi $\left.\mathrm{m}^{-3}\right]$ (solid line in Fig. 7 (f)). The surface $\mathrm{Si}(\mathrm{OH})_{4}$ increase

13 enhanced surface diatom growth (Fig. 8 (b)) and increased surface diatom biomass by a factor of 4.3

14 (solid green line in Fig. 7 (a)). The surface diatom increase resulted in a remarkable switch in feeding

15 by mesozooplankton from microzooplankton to diatoms as the source $\mathrm{Si}(\mathrm{OH})_{4}$ increased (Fig. 8 (b),

16 (d)). The declined predation on microzooplankton by mesozooplankon enhanced grazing pressure on

17 picoplankton by microzooplankton (Fig. 8 (a)), causing a decrease in surface picoplankton biomass

18 with source $\mathrm{Si}(\mathrm{OH})_{4}$ increase (solid line in Fig. 7 (a)). The decrease in surface picoplankton biomass

19 was more rapid with lower source $\mathrm{Si}(\mathrm{OH})_{4}$ concentrations.

The surface diatom increase with source $\mathrm{Si}(\mathrm{OH})_{4}$ concentration also yielded a slight switch in

21 grazing by mesozooplankton from coccolithophorids to diatoms (Fig. 8 (b), (c)), which increased

22 surface coccolithophorid biomass (Fig. 7 (b)). The surface coccolithophorid biomass had its maximum

23 at source $\mathrm{Si}(\mathrm{OH})_{4}=8-9\left[\mathrm{mmolSi} \mathrm{m}^{-3}\right]$ and then decreased with higher source $\mathrm{Si}(\mathrm{OH})_{4}$ concentrations due 
1 to slight $\mathrm{NO}_{3}$ regulation on the coccolithophorid growth as the result of higher diatom growth (solid

2 lines in Fig. 7 (b), (e), and Fig. 8 (b), (c)). The total phytoplankton biomass in the surface water had its

3 minimum at source $\mathrm{Si}(\mathrm{OH})_{4}=5\left[\mathrm{mmolSi} \mathrm{m}^{-3}\right]$ (solid line in Fig. 7 (c)). The phytoplankton composition

4 ratio in the surface water was 80,11 , and $9 \%$ at source $\mathrm{Si}(\mathrm{OH})_{4}=3\left[\mathrm{mmolSi} \mathrm{m}^{-3}\right] ; 52,33$, and $15 \%$ at

5 source $\mathrm{Si}(\mathrm{OH})_{4}=7.5\left[\mathrm{mmolSi} \mathrm{m}^{-3}\right]$; and 46,42 , and $12 \%$ at source $\mathrm{Si}(\mathrm{OH})_{4}=15\left[\mathrm{mmolSi} \mathrm{m}^{-3}\right]$ (

6 lines in Fig. 7 (d)), indicating substantial increase in diatoms and decrease in picoplankton and

7 relatively similar coccolithophorid biomass with source $\mathrm{Si}(\mathrm{OH})_{4}$ increase.

Surface TAlk is taken up by the coccolithophorids' calcification process. Hence, TAlk had its

9 minimum with source $\mathrm{Si}(\mathrm{OH})_{4}=7-8\left[\mathrm{mmolSi} \mathrm{m}^{-3}\right]$ at which surface coccolithophorids biomass had its

10 maximum (solid lines in Fig. 7 (b), (g)). The surface $\mathrm{TCO}_{2}$, which is taken up by both phytoplankton

11 growth and calcification, had its maximum with source $\mathrm{Si}(\mathrm{OH})_{4}=7\left[\mathrm{mmolSi} \mathrm{m}^{-3}\right]$, mainly as the result

12 of the lowest total phytoplankton biomass in the surface water (solid line in Fig. 7 (c) and (h)). The

$13 \mathrm{pCO}_{2 \text { sea }}$ decreases with TAlk increase and increases with $\mathrm{TCO}_{2}$ increase. The two opposite changes in

14 the $\mathrm{pCO}_{2 \text { sea }}$ by TAlk and $\mathrm{TCO}_{2}$ varies formed a maximum $\mathrm{pCO}_{2 \text { sea }}$ with source $\mathrm{Si}(\mathrm{OH})_{4}=7[\mathrm{mmolSi}$

$15 \mathrm{~m}^{-3}$ ] (solid line in Fig. 7 (i)). The $\mathrm{pCO}_{2 \text { sea }}$ changed from 357 to 401 [ $\mu \mathrm{atm}$ ], in a similar range as

16 observed (e.g., Feely et al., 1997).

17 With source $\mathrm{Si}(\mathrm{OH})_{4}$ increase, or with surface diatom biomass increase, the modeled $\mathrm{bSiO}_{2}$

18 export at $120 \mathrm{~m}$ depth dramatically increased by a factor of 6.6 from 0.38 to 2.52 [mmolSi m${ }^{-2}$ day $^{-1}$ ]

19 (solid line in Fig. 9 (a)). The modeled PON or POC export at 120m depth also increased with source

$20 \mathrm{Si}(\mathrm{OH})_{4}$ concentrations, but only slightly by a factor of 1.2 . The modeled PIC export at $120 \mathrm{~m}$ depth

21 changed by a factor of 1.6 from 0.38 to $0.60\left[\mathrm{mmolC} \mathrm{m}^{-2}\right.$ day $\left.^{-1}\right]$ and had its maximum around the

22 standard source $\mathrm{Si}(\mathrm{OH})_{4}$ concentration of 7.5 [mmolSi m ${ }^{-3}$ ] (Fig. 9 (b)). The difference in the curve

23 among PON or POC, $\mathrm{bSiO}_{2}$, and PIC appeared because PON or POC was produced by fecal pellet and 
1 phytoplankton mortality, while $\mathrm{bSiO}_{2}$ and PIC were only produced by diatoms and coccolithophorids,

2 respectively. The modeled $\mathrm{bSiO}_{2}: \mathrm{PON}$ export ratio at $120 \mathrm{~m}$ depth changed by a factor of 5.6 , from 0.7

3 to 3.9 with source $\mathrm{Si}(\mathrm{OH})_{4}$ concentrations (solid line in Fig. 9 (c)). The larger extent of change in $\mathrm{bSiO}_{2}$

4 export with source $\mathrm{Si}(\mathrm{OH})_{4}$ concentrations (solid line in Fig. 9 (a)) than of surface diatom biomass (by

5 a factor of 4.3; solid line in Figs. 7 (a)) suggests sedimented detritus under the equatorial Pacific

6 upwelling region act as an amplifier of changes in surface properties (Dugdale et al., 2002). The

7 modeled PIC:POC export ratio (rain ratio) at $120 \mathrm{~m}$ depth changed by a factor of 1.5 from 0.11 to 0.16 ,

8 and its maximum appeared at source $\mathrm{Si}(\mathrm{OH})_{4}=7$, close to the standard concentration of 7.5 [mmolSi

$\left.9 \mathrm{~m}^{-3}\right]($ Fig. $9(\mathrm{~d}))$.

The model results showed that $\mathrm{pCO}_{2 \text { sea }}$ and export $\mathrm{PIC}: \mathrm{POC}$ and $\mathrm{bSiO}_{2}: \mathrm{PON}$ ratios, all of

11 which are excellent indices for assessing abilities of $\mathrm{CO}_{2}$ release to the atmosphere and detritus

12 sedimentations in the equatorial Pacific, were sensitive to source $\mathrm{Si}(\mathrm{OH})_{4}$ concentrations. In particular,

13 the carbonate system in the surface water, PIC export, and the rain ratio at $120 \mathrm{~m}$ depth had their peaks

14 near the standard source $\mathrm{Si}(\mathrm{OH})_{4}$ concentration of $7.5\left[\mathrm{mmolSi} \mathrm{m}^{-3}\right]$, suggesting sensitive change in the

$15 \mathrm{CO}_{2}$ release to the atmosphere within a narrow range of the source $\mathrm{Si}(\mathrm{OH})_{4}$ concentrations presumably

16 caused by the physical forcing in the equatorial Pacific upwelling region.

17

\subsubsection{Comparison with no-calcification model results}

By eliminating coccolithophorids in the no-calcification model simulation, grazing on diatoms

20 by mesozooplankton was elevated in order to compensate the missing grazing pathway from 21 coccolithophorids to mesozooplankton (Fig. 10 (b)). Therefore, the diatom biomass was lower and the $22 \mathrm{Si}(\mathrm{OH})_{4}$ concentration was higher in the no-calcification model simulation (Fig. 7 (a), (f)). For the 23 same reason, the predation on microzooplankton by mesozooplankton was also elevated in the 
1 no-calcification model simulation (Fig. 10 (c)). The greater predation on microzooplankton by

2 mesozooplankton alleviated grazing pressure on picoplankton by microzooplankton (Fig. 10 (a)),

3 which yielded higher surface picoplankton biomass with lower source $\mathrm{Si}(\mathrm{OH})_{4}$ concentrations in the

4 no-calcification model simulation (Fig. 7 (a)). As the source $\mathrm{Si}(\mathrm{OH})_{4}$ concentration increased, the

5 surface diatom biomass increased, which lead to dominant mesozooplankton's grazing on diatoms over

6 predation on microzooplankton, in both models (Figs. 7 (a) and 10 (b), (c)). But the amplitude of

7 decrease in predation on microzooplankton with source $\mathrm{Si}(\mathrm{OH})_{4}$ concentrations was greater in the

8 no-calcification model simulation (Fig. 10 (c)), which yielded greater amplitude of increase in grazing

9 on picoplankton by microzooplankton and decrease in the surface picoplankton biomass (Figs. 7 (a)

10 and 10 (a)) than in the calcification model simulation. The surface diatom biomass was constantly

11 lower in the no-calcification model simulation because of substantially higher grazing pressure by

12 mesozooplankton than seen in the calcification model simulation (Figs. 7 (a) and 10 (b)).

The total phytoplankton biomass in the surface water decreased with source $\mathrm{Si}(\mathrm{OH})_{4}$ increase

14 in the no-calcification model simulation (dotted line in Fig. 7 (c)), which was followed by increases in

15 surface $\mathrm{NO}_{3}$ and $\mathrm{TCO}_{2}$ concentrations (dotted line in Fig. 7 (e), (h)). The surface TAlk was higher and

16 was kept constant in the no-calcification model simulation (dotted line in Fig. 7 (g)). Therefore, the

$17 \mathrm{pCO}_{2 \text { sea }}$ change in the no-calcification model simulation, increasing linearly with source $\mathrm{Si}(\mathrm{OH})_{4}$, from

18326 to 380 [ $\mu \mathrm{atm}$ ], was primarily controlled by the surface $\mathrm{TCO}_{2}$ change (dotted line in Fig. 7 (h), (i)).

19 The lower surface total phytoplankton and diatom biomass in the no-calcification model simulation

20 resulted in lower export fluxes of $\mathrm{PON}$ or $\mathrm{POC}$ and $\mathrm{bSiO}_{2}$, and a lower $\mathrm{bSiO}_{2}: \mathrm{PON}$ export ratio than in

21 the calcification model simulation (Figs. 7 (a), (c) and 9 (a), (c)). 


\section{$1 \quad$ 4.3. Comparison with field data}

The passage of the TIWs during the JGOFS TT012 cruise gave a natural experiment of how

3 the surface nutrients and ecosystem might respond to changes in source nutrients for comparison with

4 the model sensitivity experiments carried out in this study (Dugdale et al., 2002). The source $\mathrm{Si}(\mathrm{OH})_{4}$

5 increased dramatically from a minimum of $6\left[\mathrm{mmolSi} \mathrm{m}^{-3}\right]$ in early October to a maximum of 13

$6\left[\right.$ mmolSi m$\left.{ }^{-3}\right]$ by October 16,1992 , while the source $\mathrm{NO}_{3}$ concentration varied from a low of 10

$7\left[\mathrm{mmolN} \mathrm{m} \mathrm{m}^{-3}\right]$ to a maximum of $14\left[\mathrm{mmolN} \mathrm{m}^{-3}\right]$ (Fig. 11 (c), (d)). Large increases in chlorophyll

8 concentration and net community production, particularly for diatoms, were observed during this event

9 (Fig. 11 (a) and (b); Iriarte and Fryxell, 1995; Barber et al., 1996).

We compared the model results in Experiment 2 with the JGOFS TT012 cruise data during the

11 passage of the TIWs (Fig. 12). Because the source $\mathrm{Si}(\mathrm{OH})_{4}$ concentration was enhanced by the TIWs

12 (Fig. 12 (d)), the x-axes in Fig. 12 clearly correspond to the time series. The profiles of state variables

13 in the surface water vs. source $\mathrm{Si}(\mathrm{OH})_{4}$ concentrations showed that the model results well captured the

14 observed features during the passage of the TIWs, such as a linear surface $\mathrm{Si}(\mathrm{OH})_{4}$ increase with source

$15 \mathrm{Si}(\mathrm{OH})_{4}$ increase (Fig. 12 (b)), and maxima of surface $\mathrm{NO}_{3}, \mathrm{TCO}_{2}$, and $\mathrm{pCO}_{2 \text { sea }}$ at intermediate source

$16 \mathrm{Si}(\mathrm{OH})_{4}$ concentrations (Fig. 12 (a), (c), (d)). The maxima of surface $\mathrm{NO}_{3}, \mathrm{TCO}_{2}$, and $\mathrm{pCO}_{2 \text { sea }}$ were

17 regarded as results of increases and decreases in these state variables during and after the passage of the

18 TIWs, respectively.

The model results with each source $\mathrm{Si}(\mathrm{OH})_{4}$ concentration in Experiment 2 were obtained by

20 establishing steady states, running the model for 1000 days. Therefore, the model results in Experiment

212 may not reproduce the observed rapid increases in phytoplankton growth and chlorophyll

22 concentration in response to the TIWs (Fig. 11 (a), (b)). We hypothesize that this is because the

23 dramatic changes in phytoplankton growth and biomass would be caused by non steady-state biological 
1 responses to the passage of the TIWs, which may not be reproduced by Experiment 2 . 


\section{$1 \quad 5$. Concluding remarks}

To understand factors and mechanisms controlling carbon and silicon cycling in the equatorial

3 Pacific upwelling region, an ecosystem model with coccolithophorids and its calcification processes

4 has been constructed. We examined biogeochemical responses to the tropical instability waves with

5 increases of source $(120 \mathrm{~m}$ depth $) \mathrm{Si}(\mathrm{OH})_{4}$ concentration. The model results revealed the top-down

6 control (grazing by zooplankton) on phytoplankton biomass and bottom-up control (nutrient limitations,

7 especially $\mathrm{Si}(\mathrm{OH})_{4}$ limitation on diatom growth) on phytoplankton growth.

The model sensitivity study to the increase of source (120m depth) $\mathrm{Si}(\mathrm{OH})_{4}$ concentration

9 showed linear increase in surface diatoms and biogenic silica export, decrease in surface picoplankton,

10 and a maximum surface coccolithophorids at intermediate source $\mathrm{Si}(\mathrm{OH})_{4}$ concentrations. Surface total

11 alkalinity and total $\mathrm{CO}_{2}$ had the minimum and maximum, respectively, at intermediate source $\mathrm{Si}(\mathrm{OH})_{4}$

12 concentrations, which produced highest $\mathrm{CO}_{2}$ release to the atmosphere with the source $\mathrm{Si}(\mathrm{OH})_{4}$

13 concentration of $7.5\left[\mathrm{mmolSi} \mathrm{m} \mathrm{m}^{-3}\right]$. The export ratio of PIC to particulate organic carbon (rain ratio) at

$14120 \mathrm{~m}$ depth had its maximum of 0.16 with the source $\mathrm{Si}(\mathrm{OH})_{4}$ concentration of $7.5\left[\mathrm{mmolSi} \mathrm{m}{ }^{-3}\right]$,

15 suggesting a significant PIC sedimentation in the equatorial Pacific upwelling region. Enhanced change

16 in biogenic silica export flux than in surface diatom biomass suggests that sedimented detritus under

17 the region acts as an amplifier of changes in surface properties.

Comparison between calcification and no-calcification model results revealed that the

19 presence of coccolithophorids persistently elevated diatom biomass and export fluxes of detritus while

20 it decreased total alkalinity and enhanced $\mathrm{CO}_{2}$ release to the atmosphere. Large changes in the

21 carbonate system in responses to source $\mathrm{Si}(\mathrm{OH})_{4}$ concentrations suggest that physical forcing, such as

22 the tropical instability waves, Kelvin waves, and La Niña, significantly affect the carbon and silicon

23 fluxes in the region. 
To better understand the carbon and silicon cycling in the equatorial Pacific upwelling region,

2 we need more information on the processes regulating calcifiers and PIC, not only in the surface but

3 also in the subsurface layer where the calcification is considered significant.

4

5

6 Acknowledgements. The authors thank two anonymous reviewers for improving the manuscript, and

7 Drs. Richard Dugdale, Richard Barber, and Tsung-Hung Peng for the discussion on comparison with

8 observations in the equatorial Pacific. Funding for this work was provided to F. Chai by a NSF grant

9 (OCE-0137272) and a NASA grant (NAG5-9348) and to M. Fujii by MEXT through Special

10 Coordination Funds for Promoting Science and Technology.

11

12

13 


\section{Appendix}

\section{A.1 Governing equations}

4 The model equations describing each compartment all take the form:

$5 \quad \frac{\partial C_{i}}{\partial t}\left[\mathrm{mmol} \mathrm{m}^{-3} \mathrm{day}^{-1}\right]=\operatorname{PHYSICS}\left(C_{i}\right)+\operatorname{BIOLOGY}\left(C_{i}\right)$,

$6 \quad \mathrm{i}=1, \ldots, 13$.

7 The term PHYSICS $\left(\mathrm{C}_{\mathrm{i}}\right)$ represents the contribution to the concentration change due to physical

8 processes, including vertical advection and eddy diffusion:

$9 \operatorname{PHYSICS}\left(C_{i}\right)\left[\mathrm{mmol} \mathrm{m}^{-3} d a y^{-1}\right]=\underbrace{-W \frac{\partial C_{i}}{\partial z}}_{\text {advection }}+\underbrace{\frac{\partial}{\partial z}\left(A_{T v} \frac{\partial C_{i}}{\partial z}\right)}_{\text {eddy diffusivity }}$,

10 where $\mathrm{W}$ is vertical velocity, and $\mathrm{A}_{\mathrm{Tv}}$ is vertical coefficient. The term BIOLOGY (Ci) represents

11 biological sources and sinks of that compartment. In the euphotic zone (the upper $120 \mathrm{~m}$ ), the biological

12 terms, BIOLOGY(Ci) are:

13

$$
\operatorname{BIOLOGY}(P 1)\left[\text { mmolN m}^{-3} d a y^{-1}\right]=\underbrace{N P 1+R P 1}_{\text {growth }}-\underbrace{G_{1}}_{\text {grazing by } Z 1},
$$

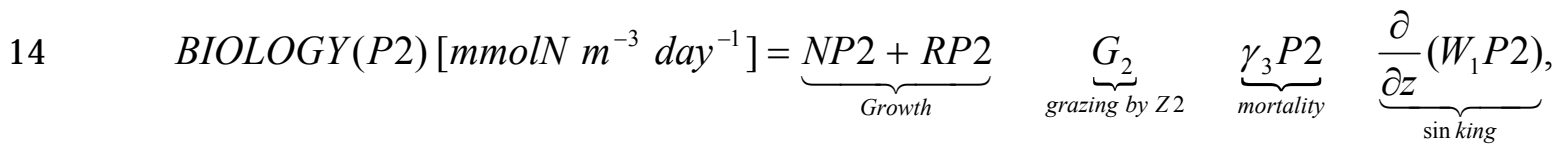

15

$$
\operatorname{BIOLOGY}(P 3)\left[\text { mmolN }^{-3} d a y^{-1}\right]=\underbrace{N P 3+R P 3}_{\text {growth }}-\underbrace{G_{5}}_{\text {grazing by Z2 }}-\underbrace{\gamma_{6} P 3}_{\text {mortality }}-\underbrace{\frac{\partial}{\partial z}\left(W_{3} P 3\right)}_{\text {sin king }},
$$

$$
\operatorname{BIOLOGY}(\mathrm{Z1})\left[\mathrm{mmolN} \mathrm{m}^{-3} \text { day }{ }^{-1}\right]=\underbrace{G_{1}}_{\text {grazing on } P 1}-\underbrace{G_{3}}_{\text {predationby } Z 2}-\underbrace{r e g_{1} Z 1}_{\text {excretion }},
$$




$$
\operatorname{BIOLOGY}(Z 2)\left[\mathrm{mmolN} \mathrm{m}^{-3} d a y^{-1}\right]=\underbrace{\gamma_{1}\left(G_{2}+G_{3}+G_{4}+G_{5}\right)}_{\text {fecal pullet }}-\underbrace{r e g_{2} Z 2}_{\text {excretion }}-\underbrace{\gamma_{2} Z 2^{2}}_{\text {loss }}
$$

$$
\operatorname{BIOLOGY}\left(\mathrm{NO}_{3}\right)\left[\mathrm{mmolN} \mathrm{m}^{-3} d a y^{-1}\right]=-\underbrace{N P 1}_{\text {uptakeby } P 1}-\underbrace{N P 2}_{\text {uptake by } P 2}-\underbrace{N P 3}_{\text {uptake by } P 3}+\underbrace{\gamma_{5} N H_{4}}_{\text {nitrification }} \text {, }
$$

$$
\begin{aligned}
\operatorname{BIOLOGY}\left(\mathrm{NH}_{4}\right)\left[\mathrm{mmolN} \mathrm{m}^{-3} \text { day } \mathrm{I}^{-1}\right] & =-\underbrace{R P 1}_{\text {uptakeby } P 1}-\underbrace{R P 2}_{\text {uptakeby } P 2}-\underbrace{R P 3}_{\text {uptake by } P 3} \\
& +\underbrace{r e g_{1} Z 1+\operatorname{reg}_{2} Z 2}_{\text {excretion }}+\underbrace{\gamma_{7} P O N}_{\text {PON re min eralization }}-\underbrace{\gamma_{5} N H_{4}}_{\text {nitrification }},
\end{aligned}
$$

$$
\operatorname{BIOLOGY}\left(\mathrm{Si}(\mathrm{OH})_{4}\right)\left[\mathrm{mmolSi} \mathrm{m}^{-3} \mathrm{day}^{-1}\right]=-\underbrace{R_{\text {SiN }}(\mathrm{NP} 2+\mathrm{RP} 2)}_{\text {silicification }}+\underbrace{\gamma_{4} b \mathrm{SiO}_{2}}_{\text {bSiO2 dissolution }}
$$

$$
\operatorname{BIOLOGY(PON)}\left[\mathrm{mmolNm}^{-3} \mathrm{day}^{-1}\right]=\underbrace{\left(1-\gamma_{1}\right)\left(G_{2}+G_{3}+G_{4}+G_{5}\right)}_{\text {fecal pullet }}-\underbrace{G_{4}}_{\text {grazing by Z2 }}+\underbrace{\gamma_{3} P 2}_{P 2 \text { mortality }}
$$

$$
+\underbrace{\gamma_{6} P 3}_{P 3 \text { mortality }}-\underbrace{\gamma_{7} P O N}_{\text {PON remineralization }}-\underbrace{\frac{\partial}{\partial z}\left(W_{2} P O N\right)}_{\text {sinking }}
$$

$6 \quad \operatorname{BIOLOGY}\left(\mathrm{bSiO}_{2}\right)\left[\mathrm{mmolSi} \mathrm{m}^{-3}\right.$ day $\left.{ }^{-1}\right]=\underbrace{R_{\text {SiN }} G_{2}}_{\text {fecal pullet }}-\underbrace{\gamma_{4} b \operatorname{SiO} \mathrm{O}_{2}}_{\text {dissolution }}+\underbrace{\gamma_{3} R_{\text {SiN }} P 2}_{P 2 \text { mortality }}-\underbrace{\frac{\partial}{\partial z}\left(W_{4} b \mathrm{SiO}_{2}\right)}_{\text {sin } \text { king }}$,

$$
\operatorname{BIOLOGY(PIC)}\left[\mathrm{mmolCm}^{-3} d a y^{-1}\right]=\underbrace{R_{C N} \varepsilon G_{5}}_{\text {fecal pullet }}-\underbrace{\gamma_{8} P I C}_{\text {dissolution }}+\underbrace{\gamma_{6} R_{C N} \varepsilon P 3}_{P 3 \text { mortality }}-\underbrace{\frac{\partial}{\partial z}\left(W_{5} P I C\right)}_{\text {sin king }} .
$$

8 Each biological process is described in next subsection. See Table 1 for abbreviations. PIC production reduces TAlk, and PIC dissolution increases TAlk (e.g. Broecker and Peng, 1982). Brewer and Goldman (1976) demonstrated that the phytoplankton growth could affect TAlk

11 through nutrient uptake of nutrients as well. Uptake of $\mathrm{NO}_{3}$ caused an increase in TAlk, whereas uptake 12 of $\mathrm{NH}_{4}$ produced a decrease. This is because one mole of $\mathrm{NO}_{3}$ assimilation by phytoplankton generates 13 one equivalent of strong base $\left(\mathrm{OH}^{-}\right)$, and for $\mathrm{NH}_{4}$, one equivalent of strong acid $\left(\mathrm{H}^{+}\right)$. Therefore, the 14 biological term for TAlk is written as follows: 
BIOLOGY(TAlk) $\left[\mathrm{mmolm}^{-3} d a y^{-1}\right]=2.0 \times\{\underbrace{\gamma_{8} P I C}_{\text {PIC dissolution }}-\underbrace{R_{C N} \varepsilon(N P 3+R P 3)}_{\text {calcification }}\}$

$$
-\operatorname{BIOLOGY}\left(\mathrm{NO}_{3}\right)+\operatorname{BIOLOGY}\left(\mathrm{NH}_{4}\right) \text {. }
$$

3 of $\mathrm{TCO}_{2}$ in the water column can be given as

$4 \frac{\partial\left(\mathrm{TCO}_{2}\right)}{\partial t}\left[\mathrm{mmolC} \mathrm{m}^{-3} d a y^{-1}\right]=\operatorname{PHYSICS}\left(\mathrm{TCO}_{2}\right)+\operatorname{BIOLOGY}\left(\operatorname{TCO}_{2}\right)+\operatorname{EVASION}\left(\operatorname{TCO}_{2}\right)$,

$$
\begin{aligned}
& \operatorname{BIOLOGY}\left(\mathrm{TCO}_{2}\right)\left[\mathrm{mmolC} \mathrm{m}^{-3} \mathrm{day}^{-1}\right]=\underbrace{\gamma_{8} P I C}_{\text {PIC dissolution }}-\underbrace{R_{C N} \varepsilon(N P 3+R P 3)}_{\text {calcification }} \\
& +R_{C N} \operatorname{BIOLOGY}\left(\mathrm{NO}_{3}\right)+R_{\mathrm{CN}} \operatorname{BIOLOGY}\left(\mathrm{NH}_{4}\right),
\end{aligned}
$$

$6 \operatorname{EVASION}\left(\mathrm{TCO}_{2}\right)\left[\mathrm{mmolC}^{-3} \mathrm{day}^{-1}\right]=\mathrm{EApCO}_{2}$,

7 where $\mathrm{E}$ is the mean $\mathrm{CO}_{2}$ exchange coefficient of $0.0391\left[\mathrm{mmolC} \mathrm{m}^{-3} \mathrm{day}^{-1} \mathrm{ppm}^{-1}\right]$ at partial pressure of $8 \mathrm{CO}_{2}\left(\mathrm{pCO}_{2}\right)$ of $280 \mathrm{ppm}$, and $\Delta \mathrm{pCO}_{2}$ is the difference in $\mathrm{pCO}_{2}$ between surface water and atmosphere.

9 The atmospheric $\mathrm{pCO}_{2}$ is assumed to be constant at $357 \mathrm{ppm}$ (Chai et al., 2002). The EVASION $\left(\mathrm{TCO}_{2}\right)$

10 term is only applied to the surface level, and is equal to zero in the water column below surface level. 


\section{$1 \quad A .2 \quad$ Formulation of biological processes}

2

3 (Irradiance)

$4 \quad \mathrm{I}\left[\mathrm{W} \mathrm{m} \mathrm{m}^{-2}\right]=\mathrm{I}_{0} \exp \left\{-\mathrm{k}_{1} \mathrm{z}-\mathrm{k}_{2} \int_{-\mathrm{z}}^{0}(\mathrm{P} 1+\mathrm{P} 2+\mathrm{P} 3) \mathrm{dz}\right\}$

$5 \mathrm{I}_{0}\left[\mathrm{~W} \mathrm{~m}{ }^{-2}\right]= \begin{cases}\mathrm{I}_{0}^{\mathrm{Noon}} \sin \left(\frac{\mathrm{t}-6}{12} \pi\right) & (\text { from } 6 \mathrm{am} \text { to } 6 \mathrm{pm}), \\ 0 & (\text { from } 6 \mathrm{pm} \text { to } 6 \mathrm{am}),\end{cases}$

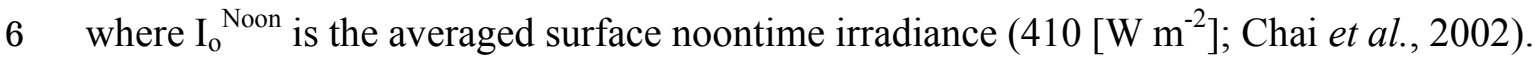

7

$8 \quad\left(\mathrm{NO}_{3}\right.$ uptake by picoplankton)

$9 \quad \mathrm{NP} 1\left[\mathrm{mmolN} \mathrm{m}^{-3} \mathrm{day}^{-1}\right]=\mu 1_{\max } \underbrace{\frac{\mathrm{NO}_{3}}{\mathrm{~K}_{\mathrm{NO}_{3}}+\mathrm{NO}_{3}}}_{\mathrm{NO}_{3} \text { regulation }} \underbrace{\mathrm{e}^{-\Psi \mathrm{NH}_{4}}}_{\mathrm{MH}_{4} \text { inhibition }} \underbrace{\left(1-\mathrm{e}^{-\frac{\alpha}{\mu 1_{\max }}}\right)}_{\text {light regulation }} \mathrm{P} 1$.

10

$11 \quad\left(\mathrm{NH}_{4}\right.$ uptake by picoplankton)

12

$$
\mathrm{RP} 1\left[\mathrm{mmolN} \mathrm{m}{ }^{-3} \mathrm{day}^{-1}\right]=\mu 1_{\max } \underbrace{\frac{\mathrm{NH}_{4}}{\mathrm{~K}_{\mathrm{NH}_{4}}+\mathrm{NH}_{4}}}_{\mathrm{NH}_{4} \text { regulation }} \underbrace{\left(1-\mathrm{e}^{-\frac{\alpha}{\mu 1_{\max }}}\right)}_{\text {light regulation }} \mathrm{P} 1 .
$$

13

$14 \quad\left(\mathrm{NO}_{3}\right.$ and $\mathrm{NH}_{4}$ uptake by diatoms $)$

15 If $\frac{1}{R_{\mathrm{SiN}}} \frac{\mathrm{Si}(\mathrm{OH})_{4}}{K_{\mathrm{Si}(\mathrm{OH})_{4}}+\mathrm{Si}(\mathrm{OH})_{4}}>\frac{\mathrm{NH}_{4}}{\mathrm{~K}_{\mathrm{P} 2_{-} \mathrm{NH}_{4}}+\mathrm{NH}_{4}}$, 


$$
\times \underbrace{\left(1-e^{-\frac{\alpha}{\mu 2_{\max }} I}\right)}_{\text {light regulation }} P 2,
$$

$$
\mathrm{RP} 2\left[\mathrm{mmolN} \mathrm{m}^{-3} \mathrm{day}^{-1}\right]=\mu 2_{\max } \underbrace{\frac{\mathrm{NH}_{4}}{\mathrm{~K}_{\mathrm{P}_{2} \mathrm{NH}_{4}}+\mathrm{NH}_{4}}}_{\mathrm{NH}_{4} \text { regulation }} \underbrace{\left(1-\mathrm{e}^{-\frac{\alpha}{\mu 2_{\max }}}\right)}_{\text {light regulation }} \mathrm{P} 2 .
$$

3 If $\frac{1}{R_{\mathrm{SiN}}} \frac{\mathrm{Si}(\mathrm{OH})_{4}}{K_{\mathrm{Si}(\mathrm{OH})_{4}}+\mathrm{Si}(\mathrm{OH})_{4}} \leq \frac{\mathrm{NH}_{4}}{\mathrm{~K}_{\mathrm{P} 2_{-} \mathrm{NH}_{4}}+\mathrm{NH}_{4}}$,

4

$$
\mathrm{NP} 2=0,
$$

5

$$
R P 2=\mu 2_{\max } \frac{1}{R_{S i N}} \frac{\mathrm{Si}(\mathrm{OH})_{4}}{K_{S i(\mathrm{OH})_{4}}+\mathrm{Si}(\mathrm{OH})_{4}} \underbrace{\left(1-e^{-\frac{\alpha}{\mu 2_{\max }}}\right)}_{\text {light regulation }} P 2 .
$$

6

$7 \quad\left(\mathrm{NO}_{3}\right.$ uptake by coccolithophorids)

$8 \quad \mathrm{NP} 3\left[\mathrm{mmolN} \mathrm{m}^{-3} \mathrm{day}^{-1}\right]=\mu 3_{\max } \underbrace{\frac{\mathrm{NO}_{3}}{\mathrm{~K}_{\mathrm{P}_{2} \mathrm{NO}_{3}}+\mathrm{NO}_{3}}}_{\mathrm{NO}_{3} \text { regulation }} \underbrace{\mathrm{e}^{-\Psi \mathrm{NH}_{4}}}_{\mathrm{NH}_{4} \text { inhibition }} \underbrace{\left(1-\mathrm{e}^{-\frac{\alpha}{\mu 3_{\max }}} \mathrm{I}\right.}_{\text {light regulation }} \mathrm{P} 3$.

9

$10 \quad\left(\mathrm{NH}_{4}\right.$ uptake by coccolithophorids $)$

$11 \mathrm{RP} 3\left[\mathrm{mmolN} \mathrm{m}^{-3} \mathrm{day}^{-1}\right]=\mu 3_{\max } \underbrace{\frac{\mathrm{NH}_{4}}{\mathrm{~K}_{\mathrm{P}_{3} \mathrm{NH}_{4}}+\mathrm{NH}_{4}}}_{\mathrm{NH}_{4} \text { regulation }} \underbrace{\left(1-\mathrm{e}^{-\frac{\alpha}{\mu 3_{\max }}}\right)}_{\text {light regulation }} \mathrm{P} 3$.

13 (Grazing on picoplankton by microzooplankton) 
$1 \quad \mathrm{G}_{1}\left[\mathrm{mmolN} \mathrm{m}^{-3} \mathrm{day}^{-1}\right]=\mathrm{G} 1_{\max } \underbrace{\frac{\mathrm{P} 1}{\mathrm{~K} 1_{\mathrm{gr}}+\mathrm{P} 1}}_{\text {food lim itation }} \underbrace{\frac{\mathrm{P} 1}{\mathrm{P} 1_{\text {ave }}}}_{\text {depth mod ification }} \mathrm{Z}$,

$2 \quad \mathrm{P}_{\mathrm{ave}}\left[\mathrm{mmolN} \mathrm{m}{ }^{-3} \mathrm{day}^{-1}\right]=\frac{1}{\mathrm{Z}^{\prime}} \int_{-\mathrm{Z}^{\prime}}^{0} \mathrm{Pld}$,

3 where $Z^{\prime}$ is the depth of the euphotic zone (120m).

4

5 (Grazing or predation on diatoms, coccolithophorids, microzooplankton, and PON by 6 mesozooplankton)

$7 \quad \mathrm{G}_{2}\left[\mathrm{mmolN} \mathrm{m}^{-3} \mathrm{day}^{-1}\right]=\mathrm{G} 2_{\max } \frac{\zeta_{1} \mathrm{P} 2}{\mathrm{~K} 2_{\mathrm{gr}}+\zeta_{1} \mathrm{P} 2+\zeta_{2} \mathrm{Z} 1+\zeta_{3} \mathrm{PON}+\zeta_{4} \mathrm{P} 3} \mathrm{Z} 2$

$8 \quad \mathrm{G}_{3}\left[\mathrm{mmolN} \mathrm{m}^{-3} \mathrm{day}^{-1}\right]=\mathrm{G} 2_{\max } \frac{\zeta_{2} \mathrm{Z} 1}{\mathrm{~K} 2_{\mathrm{gr}}+\zeta_{1} \mathrm{P} 2+\zeta_{2} \mathrm{Zl}+\zeta_{3} \mathrm{PON}+\zeta_{4} \mathrm{P} 3} \mathrm{Z} 2$,

$9 \quad \mathrm{G}_{4}\left[\mathrm{mmolN} \mathrm{m}^{-3} \mathrm{day}^{-1}\right]=\mathrm{G} 2_{\max } \frac{\zeta_{3} \mathrm{PON}}{\mathrm{K} 2_{\mathrm{gr}}+\zeta_{1} \mathrm{P} 2+\zeta_{2} \mathrm{Z} 1+\zeta_{3} \mathrm{PON}+\zeta_{4} \mathrm{P} 3} \mathrm{Z} 2$,

$10 \mathrm{G}_{5}\left[\mathrm{mmolN} \mathrm{m}^{-3} \mathrm{day}^{-1}\right]=\mathrm{G} 2_{\max } \frac{\zeta_{4} \mathrm{P} 3}{\mathrm{~K} 2_{\mathrm{gr}}+\zeta_{1} \mathrm{P} 2+\zeta_{2} \mathrm{Z} 1+\zeta_{3} \mathrm{PON}+\zeta_{4} \mathrm{P} 3} \mathrm{Z} 2$,

11 where

12

$$
\zeta_{1}=\frac{\rho_{1} \mathrm{P} 2}{\rho_{1} \mathrm{P} 2+\rho_{2} \mathrm{Z} 1+\rho_{3} \mathrm{PON}+\rho_{4} \mathrm{P} 3},
$$

13

$$
\zeta_{2}=\frac{\rho_{2} Z 1}{\rho_{1} \mathrm{P} 2+\rho_{2} Z 1+\rho_{3} \mathrm{PON}+\rho_{4} \mathrm{P} 3},
$$

$14 \quad \zeta_{3}=\frac{\rho_{3} \mathrm{PON}}{\rho_{1} \mathrm{P} 2+\rho_{2} \mathrm{Z} 1+\rho_{3} \mathrm{PON}+\rho_{4} \mathrm{P} 3}$, 
$1 \quad \zeta_{4}=\frac{\rho_{4} \mathrm{P} 3}{\rho_{1} \mathrm{P} 2+\rho_{2} \mathrm{Z} 1+\rho_{3} \mathrm{PON}+\rho_{4} \mathrm{P} 3}$. 


\section{References}

Archer, D., et al., 1997. A meeting place of great ocean currents: shipboard observations of a convergent front at $2^{\circ} \mathrm{N}$ in the Pacific. Deep-Sea Res. Part II 44(9-10), 1827-1849.

Armstrong, R. A., Lee, C., Hedges, J. I., Honjo, S., Wakeham, S. G.., 2002. A new, mechanistic model for organic carbon fluxes in the ocean based on the quantitative association of POC withballast models. Deep-Sea Res. Part II 49, 219-236.

Bacon, M. P., Cochran, J. K., Hirschberg, D., Hammer, T. R., Fleer, A. P., 1996. Export flux of carbon at the equator during the EqPac time-series cruises estimated from ${ }^{234} \mathrm{Th}$ measurements. Deep-Sea Res. Part II 43(4-6), 1133-1153.

Balch, W. M., Kilpatrick, K., 1996. Calcification rates in the equatorial Pacific along $140^{\circ} \mathrm{W}$. Deep-Sea Res. Part II 43 (4-6), 971-993.

Barber, R. T., Sanderson, M. P., Lindley, S. T., Chai, F., Newton, J., Trees, C. C., Foley, D. G., Chavez, F. P., 1996. Primary productivity and its regulation in the equatorial Pacific during and following the 1991-1992 El Niño. Deep-Sea Res. Part II 43 (4-6), 933-969.

Bates, T. S., Cline, J. D., Gammon, R. H., Kelly-Hansen, S., 1987. Regional and seasonal variations in the flux of ocenic dimethylsulfide to the atmosphere. J. Geophys. Res. 92, 2930-2938.

Beucher, C., Tréguer, P., Hapette, A., Corvaisier, R., Metzl, N., Pochon, J., 2004. Intense summer Si-recyling in the surface Southern Ocean. Geophys. Res. Lett. 31, L09305, doi:10.1029/2003GL018998.

Bidigare, R. R., Ondrusek, M. E., 1996. Spatial and temporal variability of phytoplankton pigment distributions in the central equatorial Pacific Ocean. Deep-Sea Res. Part II 43, 809-833.

Bidle, K. D., Azam, F, 1999. Accelerated dissolution of diatom silica by natural marine bacterial assemblages. Nature 397, 508-512.

Bidle, K. D., Manganelli, M., Azam, F., 2002. Regulation of silicon and carbon preservation by temperature control on bacteria, Science 298, 1980-1984.

Bidle, K. D., Brzezinski, M. A., Long, R. A., Jones, J. L., Azam, F., 2003. Diminished efficiency in the silica pump caused by bacteria-mediated silica dissolution. Limnol. Oceanogr. 48, 1855-1868.

Brewer, P. G., Goldman, J. C., 1976. Alkalinity changes generated by phytoplankton growth. Limnol. Oceanogr. 21, 108-117.

Broecker, W. S., Peng, T.-H., 1982. Tracers in the Sea. Lamont-Doherty Geol. Obs., Palisades, New York, 690pp.

Brown, C. W., 1999. Spatial and temporal variability of Emiliania huxleyi blooms in SeaWiFS imagery, Eos Trans. AGU, 80(49) Suppl., 153.

Brown, C. W. Yoder, J. A., 1994. Coccolithophorid blooms in the global ocean. J. Geophys. Res. 99, 7467-7482.

Buesseler, K. O., Andrews, J. A., Hartman, M. C., Belastock, R., Chai, F., 1995. Regional estimates of the export flux of particulate organic carbon derived from thorium-234 during the JGOFS EqPac program. Deep-Sea Res. Part II 42(2-3), 777-804.

Buitenhuis, E., Le Quéré, C., Aumont, O., Beaugrand, G.., Bunker, A., Hirst, A., Ikeda, T., O’Brien, T., Piontkovski, S., Straile, D., 2006. Biogeochemical fluxes through mesozooplankton. Glob. Biogeochem. Cycles 20, GB2003, doi:10.1029/2005GB002511.

Chai, F., Dugdale, R. C., Peng, T.-H., Wilkerson, F. P., Barber, R. T., 2002. One-dimensional ecosystem model of the equatorial Pacific upwelling system. Part I: model development and silicon and nitrogen cycle. Deep-Sea Res. Part II 49, 2713-2745. 
Chai, F., Lindley, S. T., Barber, R. T., 1996. Origin and maintenance of a high nitrate condition in the equatorial Pacific. Deep-Sea Res. Part II, 43(4-6), 1031-1064.

Charlson, R. J., Lovelock, J. E., Andreae, M. O., Warren, S. G., 1987. Oceanic phytoplankton, atmospheric sulphur, cloud albed and climate. Nature 326, 655-661.

Chavez, F. R., Barber, R.T., 1987. An estimate of new production in the equatorial Pacific. Deep-Sea Res. 34, 1229-1243.

Chavez, F. P., Buck, K. R., Coale, K. H., Martin, J. H., DiTullio, G. R., Welshmeyer, N. A., Jacobson, A. C., Barber, R. T., 1991. Growth rates, grazing, sinking and iron limitation of equatorial Pacific phytoplankton. Limnol. Oceanogr. 36, 1816-1833.

Chavez, F.P., Buck, K.R., Service, S.K., Newton, J., Barber, R.T., 1996. Phytoplankton variability in the central and eastern tropical Pacific. Deep-Sea Res. Part II 43, 835-870.

Coale, K. H., Johnson, K. S., Fitzwater, S. E., Gordon, R. M., Tanner, S., Chavez, F. P., Ferioli, L., Sakamoto, C., Rogers, P., Millero, F., Steinberg, P., Nightingale, P., Cooper, D., Cochlan, W. P., Landry, M. R., Constantinou, J., Rollwagen, G., Trasvina, A., Kudela, R., 1996. A massive phytoplankton bloom induced by an ecosystem-scale iron fertilization experiment in the equatorial Pacific Ocean. Nature, 383, 495-501.

Conkright, M. E., Antonov, J. I., Baranova, O., Boyer, T. P., Garcia, H. E., Gelfeld, R., Johnson, D. D., Locarnini, R. A., Murphy, P. P., O’Brien, T. D., Smolyar, I., Stephens, C., 2002. World Ocean Database 2001, Volume 1: Introduction. Ed: S. Levitus, NOAA Atlas, NESDIS 42, U.S. Government Printing Office, Washington, D.C., 167pp.

Deuser, W. G., Ross, E. H., 1989. Seasonally abundant planktonic-foraminifera of the Sargasso Sea : Succession, deep-water fluxes, isotopic compositions, and paleoceanographic implications. J. Foraminiferal Res. 19, 268-293.

Dugdale, R.C., Barber, R. T., Chai, F., Peng, T.-H., Wilkerson, F.P., 2002. One-dimensional ecosystem model of the equatorial Pacific upwelling system. Part II: sensitivity analysis and comparison with JGOFS EqPac data. Deep-Sea Res. Part II 49, 2747-2768.

Dugdale, R.C., Wilkerson, F.P., 1998. Silicate regulation of new production in the equatorial Pacific upwelling. Nature 391, 270-273.

Dugdale, R.C., Wilkerson, F.P., Minas, H. J., 1995. The role of a silicate pump in driving new production. Deep-Sea Res. 42, 697-719.

Dunne, J.P., Murray, J.W., Aufdenkampe, A.K., Blain, S., Rodier, M., 1999. Silicon-nitrogen coupling in the equatorial Pacific upwelling zone, Global Biogeochem. Cycles 13 (3), 715-726.

Fabry, V. J., 1989. Argonite production by pteropod mollusks in the subantarctic Pacific. Deep-Sea Res. $36,1735-1751$.

Feely, R. A., Wanninkhof, R., Goyat, C., Archer, D. E., Takahashi, T., 1997. Variability of $\mathrm{CO}_{2}$ distributions and sea-air fluxes in the central and eastern equatorial Pacific during the 1991-1994 El Niño. Deep-Sea Res. Part II 44(9-10), 1851-1867.

Flament, P. J., Kennan, S. C., Knox, R. A., Niiler, P. P., Bernstein, R. L., 1996. The three-dimensional structure of an upper ocean vortex in the tropical Pacific ocean, Nature 383, 610-613.

Foley, D. G., Dickey, T. D., McPhaden, M. J., Bidigare, R. R., Lewis, M. R., Barber, R. T., Lindley, S. T., Garside, C., Monov, D. V., McNeil, J. D., 1996. Longwaves and primary productivity variations in the equatorial Pacific at $0^{\circ} \mathrm{N}, 140^{\circ} \mathrm{W}$. Deep-Sea Res. Part II 44(9-10), 1801-1826.

Francois, R., Honjo, S., Krishfield, R., Manganini, S, 2002. Factors controlling the flux of organic carbon to the bathypelagic zone of the ocean. Global Biogeochem. Cycles 16(4), 1087, doi:10.1029/2001GB011722. 
Fujii, M., Chai, F., 2005. Effects of biogenic silica dissolution on silicon cycling and export production. Geophys. Res. Lett. 32, L05617, doi:10.1029/2004GL022054.

Fujii, M., Chai, F., 2007. Influences of initial plankton conditions and mixed layer depth on the outcome of iron-fertilization experiments. submitted to J. Geophys. Res.

Fujii, M., Ikeda, M., Yamanaka, Y., 2005a. Roles of biogeochemical processes in the carbon cycle described with a simple coupled physical-biogeochemical model, J. Oceanogr. 61, 803-815.

Fujii, M., Nojiri, Y., Yamanaka, Y., Kishi, M. J., 2002. A one-dimensional ecosystem model applied to time series station KNOT. Deep-Sea Res. Part II 49, 5441-5461.

Fujii, M., Yamanaka, Y., Nojiri, Y., Kishi, M. J., Chai, F., 2007. Comparison of seasonal characteristics in biogeochemistry among the subarctic North Pacific stations described with a NEMURO-based marine ecosystem model. Ecol. Modell., doi:10.1016/j.ecolmodel.2006.02.046.

Fujii, M., Yoshie, N., Yamanaka, Y., Chai, F., 2005b. Simulated biogeochemical responses to iron enrichments in three high nutrient, low chlorophyll (HNLC) regions, Prog. Oceanogr. 64, 307-324.

Holligan, P. M., Viollier, M., Harbour, D. S., Camus, P., Champagne-Philippe, M., 1983. Satellite and ship studies of coccolithophorid production along a continental shelf edge. Nature 304, 339-342.

Iglesias-Rodríguez, M. D., Brown, C., Doney, S. C., Kleypas, J., Kolber, D., Kolber, Z., Hayes, P. K., Falkowski, P. G., 2002. Representing key phytoplankton functional groups in ocean carbon cycle models: Coccolithophores. Global Biogeochem. Cycles 16, doi:10.1029/001GB001454.

Iriarte, J. L., Fryxell, G. A., 1995. Micro-phytoplankton at the equatorial Pacific $\left(140^{\circ} \mathrm{W}\right)$ during the JGOFS EqPac time series studies: March to April 1992. Deep-Sea Res. Part II 42, 559-584.

Jiang, M.-S., Chai, F., Dugdale, R. C., Wilkerson, F. P., Peng, T.-H., Barber, R. T., 2003. A nitrate and silicate budget in the equatorial Pacific Ocean: a coupled physical-biological model study. Deep-Sea Res. Part II 50, 2971-2996.

Kessler, M. S., McPhaden, M. J., 1995. The 1991-1993 El Niño in the central Pacific. Deep-Sea Res. Part II 42, 295-333.

Ku, T. L., Luo, S., Kusakabe, M., Bishop, J. K. B., 1995. ${ }^{228}$ Ra-derived nutrient budgets in the upper equatorial Pacific and the role of "new" silicate in limiting productivity, Deep-Sea Res. Part II 42, 479-497.

Landry, M. R., Barber, R. T., Bidigare, R. R., Chai, F., Coale, K. H., Dam, H. G., Lewis, M. R., Lindley, S. T., McCarthy, J. J., Roman, M. R., Stoecker, D. K., Verity, P. G., White, J. R., 1997. Iron and grazing constraints on primary production in the central equatorial Pacific: An EqPac sysnthesis. Limnol. Oceanogr. 42, 405-418.

Landry, M. R., Ondrusek, M. E., Tanner, S. J., Brown, S. L., Constantinou, J., Bidigare, R. R., Coale, K. H., Fitzwater, S., 2000. Biological response to iron fertilization in the eastern equatorial Pacific (IronExII). I. Microplankton community abundances and biomass. Mar. Ecol. Prog. Ser. 201, 27-42.

Le Borgne, R., Bruset, C. Eldin, G., Radenac, M.-H., Rodier, M., 1995. Campagne océanographique FLUPAC à bord du N.O. l'ATALANTE. Du 23 septembre au 29 octobre 1994. Recueil des données, Tome 1. ORSTOM, Nouméa, Archives Sciences de la Mer, Océanographique, No. 1.

Le Borgne, R., Langlade, M. J., Polidori, P., Rodier, M., 1998. Campagne océanographique EBENE à bord du N.O. l'ATALANTE. Du 21 octobre au 20 novembre 1996. Recueil des données, Tome 1. ORSTOM, Nouméa, Archives Sciences de la Mer, Océanographique, No. 3. 
Levitus, S., Reid, J. L., Conkright, M. E., Najjar, R., 1993. Distribution of nitrate, phosphate and silicate in the world ocean. Prog. Oceanogr. 31, 245-273.

Leynaert, A., Treguer, P., Lancelot, C., Rodier, M., 2001. Silicon limitation of biogenic silica production in the Equatorial Pacific. Deep-Sea Res. Part I 48, 639-660.

Loukos, H., Frost, B., Harrison, D. E., Murray, J. W., 1997. An ecosystem model with iron limitation of primary production in the equatorial Pacific at $140^{\circ} \mathrm{W}$. Deep-Sea Res. Part II 44(9-10), 2221-2249.

Luo, S., Ku. T.-L., Kusakabe, M., Bishop, J. K. B., Yang, Y.-L., 1995. Tracing particle cycling in the upper ocean with ${ }^{230} \mathrm{Th}$ and ${ }^{228} \mathrm{Th}$ : An investigation in the equatorial Pacific along $140^{\circ} \mathrm{W}$. Deep-Sea Res. Part II 42(2-3), 805-829.

Martin, J. H., et al., 1994. Testing the iron hypothesis in ecosystems of the equatorial Pacific Ocean. Nature 371, 123-129.

McCarthy, J. J., C. Garside, J. L. Nevins, and R. T. Barber (1996), New production along 140W in the equatorial Pacific during and following the 1992 El Niño event, Deep-Sea Res. Part II, 43(4-6), 1065-1093.

Milliman, J. D., Troy, P. J., Balch, W. M., Adams, A. K., Li, Y.-H., MacKenzie, F. T., 1999. Biologically mediated dissolution of calcium carbonate above the chemical lysocline? Deep-Sea Res. Part I 46, 1653-1669.

Moore, J. K., Doney, S. C., Kleypas, J. A., Glover, D. M., Fung, I. Y., 2002. An intermediate complexity marine ecosystem model for the global domain. Deep-Sea Res. Part II 49, 403-462.

Murray, J. W., Johnson, E., Garside, C., 1995. A U.S. JGOFS process study in the equatorial Pacific (EqPac): Introduction. Deep-Sea Res. Part II 42(2-3), 275-293.

Murray, J. W., Leborgne, R., Dandonneau, Y., 1997. JGOFS studies in the equatorial Pacific. Deep-Sea Res. Part II 44(9-10), 1759-1763.

Murray, J.W., Young, J., Newton, J., Dunne, J., Chapin, T., Paul, B., McCarthy, J.J., 1996. Export flux of particulate organic carbon from the central equatorial pacific determined using a combined drifting trap - ${ }^{234}$ Th approach. Deep-Sea Res. Part II 43(4-6), 1095-1133.

Najjar, R. G., Orr, J. C., 1998. Design of OCMIP-2 simulations of chlorofluorocarbons, the solubility pump and common biogeochemistry. $19 \mathrm{pp}$.

Orr, J., et al., 2005. Anthropogenic ocean acidification over the twenty-first century and its impact on calcifying organisms. Nature 437, doi:10.1038/nature04095.

Pasquer, B., Laruelle, G., Becquevort, S., Schoemann, V., Goosse, H., Lancelot, C., 2005. Linking ocean biogeochemical cycles and ecosystem structure and function: results of the complex SWAMCO-4 model. J. Sea Res. 53(1-2), 93-108.

Pätsch, J., Kühn, W., Radach, G., Santana Casiano, J. M., Gonzalez Davila, M., Neuer, S., Freudenthal, T., Llinas, O., 2002. Interannual variability of carbon fluxes at the North Atlantic Station ESTOC. Deep-Sea Res. Part II 49, 253-288.

Price, N. M., Ahner, B. A., Morel, F. M. M., 1994. The equatorial Pacific Ocean: grazer controlled phytoplankton populations in an iron-limited ecosystem. Limnol. Oceanogr. 39, 520-534.

Rainbault, P., Slawyk, G., Boudjellal, B., Coatanoan, C., Conan, P., Coste, B., Garcia, N., Moutin, T., Pujo-Pay, M., 1999. Carbon and nitrogen uptake and export in the equatorial Pacific at $150^{\circ} \mathrm{W}$ : evidence of an efficient regenerated production cycle. J. Geophys. Res. 104, 3341-3356.

Riebesell, U., Zondervan, I., Rost, B., Tortell, P. D., Zeebe, R. E., Morel, F. M. M., 2000. Reduced calcification of marine plankton in response to increased atmospheric CO2. Nature 407, 364-367. 
Rodier, M., Le Borgne, R., 1997. Export flux of particles at the equator in the western and central Pacific Ocean. Deep-Sea Res. Part II 44, 2085-2113.

Sanderson, M. P., Hunter, C. N., Fitzwater, S. E., Gordon, R. M., Barber, R. T., 1995. Primary productivity and trace metal contamination measurements from a clean rosette system versus ultra-clean Go-Flo bottles. Deep-Sea Res. Part II 42, 431-441.

Sarmiento, J. L., Dunne, J., Gnanadesikan, A., Key, R. M., Matsumoto, K., Slater, R., 2002. A new estimate of the $\mathrm{CaCO}_{3}$ to organic carbon export ratio. Global Biogeochem. Cycles 16, doi:10.1029/2002GB001919.

van Andel, T. H., 1975. Cenozoic history and paleoceanography of the central equatorial Pacific Ocean. Memoirs of the Geological Society of America 143, 1-134.

Walsh, J. J., 1976. Herbivory as a factor in patterns of nutrient utilization in the sea. Limnol. Oceanogr. 21, 1-13.

Westbroek, P., Youn, P. R., Linschooten, K., 1989. Coccolith production (biomineralization) in the marine alga Emiliania huxleyi. J. Protozool. 36, 368-373.

Wyrtki, K., 1981. An estimate of equatorial upwelling in the Pacific. J. Phys. Oceanogr. 11, 1205-1214.

Yamanaka, Y., Tajika, E., 1996. The role of the vertical fluxes of particulate organic matter and calcite in the carbon cycle: Studies using an ocean biogeochemical general circulation model. Global Biogeochem. Cycles 10, 361-382.

Yamanaka, Y., Yoshie, N., Fujii, M., Aita, M. N., Kishi, M. J., 2004. An ecosystem model coupled with nitrogen-silicon-carbon cycles applied to station A7 in the northwestern Pacific. J. Oceanogr. 60, 227-241.

Yoshie, N., Fujii, M., Yamanaka, Y, 2005. Ecosystem changes after the SEEDS iron fertilization in the western North Pacific simulated by a one-dimensional ecosystem model. Prog. Oceanogr. 64, 283-306. 
1 Table 1. The model parameters. Columns (I) and (II) denotes the standard values of parameters in 2 calcification model simulation and no-calcification model simulation, respectively.

\begin{tabular}{|c|c|c|c|c|c|c|c|}
\hline \multicolumn{3}{|l|}{ Parameters } & Symbol & (I) & (II) & Unit & Source \\
\hline \multicolumn{3}{|c|}{ Light attenuation due to water } & $k_{1}$ & 0.046 & 0.046 & $\mathrm{~m}^{-1}$ & (1) \\
\hline \multicolumn{3}{|c|}{ Light attenuation by phytoplankton } & $k_{2}$ & 0.03 & 0.03 & $\mathrm{~m}^{-1}\left(\mathrm{mmolNm}^{-3}\right)^{-1}$ & (1) \\
\hline \multicolumn{3}{|c|}{ Initial slope of the P-I curve } & $\alpha$ & 0.025 & 0.025 & $\operatorname{day}^{-1}\left(\mathrm{~W} \mathrm{~m}^{-2}\right)^{-1}$ & (1) \\
\hline \multicolumn{3}{|c|}{ Maximum specific growth rate of picoplankton } & $\mu 1_{\max }$ & 2.0 & 2.0 & day $^{-1}$ & (1) \\
\hline \multicolumn{3}{|c|}{$\mathrm{NH}_{4}$ inhibition parameter } & $\Psi$ & 5.59 & 5.59 & $\left.(\mathrm{mmolN} \mathrm{m})^{-3}\right)^{-1}$ & (1) \\
\hline \multicolumn{3}{|c|}{ Half-saturation for $\mathrm{NO}_{3}$ uptake by picoplankton } & $K_{\mathrm{NO} 3}$ & 1.0 & 1.0 & mmolN m ${ }^{-3}$ & (1) \\
\hline \multicolumn{3}{|c|}{ Half-saturation for $\mathrm{NH}_{4}$ uptake by picoplankton } & $K_{\mathrm{NH} 4}$ & 0.1 & 0.1 & mmolN m ${ }^{-3}$ & This study \\
\hline \multicolumn{3}{|c|}{ Maximum specific growth rate of diatoms } & $\mu 2_{\max }$ & 3.0 & 3.0 & day $^{-1}$ & (1) \\
\hline \multicolumn{3}{|c|}{ Half-saturation for $\mathrm{Si}(\mathrm{OH})_{4}$ uptake } & $K_{\mathrm{Si}(\mathrm{OH}) 4}$ & 3.0 & 3.0 & mmolSi $\mathrm{m}^{-3}$ & (1) \\
\hline \multicolumn{3}{|c|}{ Half-saturation for $\mathrm{NH}_{4}$ uptake by diatoms } & $K_{\mathrm{P} 2 \mathrm{NH} 4}$ & 1.0 & 1.0 & mmolN m ${ }^{-3}$ & (1) \\
\hline \multicolumn{3}{|c|}{ Diatom sinking speed } & $W_{1}$ & 1.0 & 1.0 & $\mathrm{~m}_{\text {day }}{ }^{-1}$ & (1) \\
\hline \multicolumn{7}{|l|}{ coccolithophorids } & This study \\
\hline $\begin{array}{l}\text { Half-saturation for } \\
\text { coccolithophorids }\end{array}$ & \multicolumn{5}{|c|}{ coccolithophorids } & mmolN m ${ }^{-3}$ & This study \\
\hline \multicolumn{3}{|l|}{$\begin{array}{l}\text { Half-saturation } \\
\text { coccolithophorids }\end{array}$} & $K_{\mathrm{P} 3 \_\mathrm{NH} 4}$ & 1.0 & N/A & mmolN m ${ }^{-3}$ & This study \\
\hline \multicolumn{3}{|c|}{ Coccolithophorid sinking speed } & $W_{3}$ & 1.0 & N/A & $m$ day $^{-1}$ & This study \\
\hline \multicolumn{3}{|c|}{ Microzooplankton maximum specific grazing rate } & $G 1_{\max }$ & 1.25 & 1.25 & day $^{-1}$ & This study \\
\hline \multicolumn{3}{|c|}{ Half-saturation for microzooplankton ingestion } & $K 1_{\mathrm{gr}}$ & 0.5 & 0.5 & mmolN m ${ }^{-3}$ & (1) \\
\hline \multicolumn{3}{|c|}{ Microzooplankton excretion rate to $\mathrm{NH}_{4}$} & $\operatorname{reg}_{1}$ & 0.2 & 0.2 & day $^{-1}$ & (1) \\
\hline \multicolumn{3}{|c|}{ Mesozooplankton maximum specific grazing rate } & $G 2_{\max }$ & 0.48 & 0.48 & day $^{-1}$ & This study \\
\hline \multicolumn{3}{|c|}{ Mesozooplankton assimilation efficiency } & $\gamma_{1}$ & 0.75 & 0.75 & & (1) \\
\hline \multicolumn{3}{|c|}{$\begin{array}{l}\text { Half-saturation for mesozooplankton ingestion for } \\
\text { diatoms, coccolithophirids, microzooplankton and } \\
\text { PON }\end{array}$} & $K 2_{\text {gr }}$ & 0.25 & 0.25 & mmolN m${ }^{-3}$ & (1) \\
\hline \multicolumn{3}{|c|}{ Diatom specific mortality rate } & $\gamma_{3}$ & 0.05 & 0.05 & day $^{-1}$ & (1) \\
\hline \multicolumn{3}{|c|}{ Coccolithophorid specific mortality rate } & $\gamma_{6}$ & 0.05 & N/A & day $^{-1}$ & This study \\
\hline \multicolumn{3}{|c|}{ Mesozooplankton specific mortality rate } & $\gamma_{2}$ & 0.05 & 0.05 & day $^{-1}$ & (1) \\
\hline Mesozooplankton excre & rate to & $\mathrm{H}_{4}$ & $\mathrm{reg}_{2}$ & 0.1 & 0.1 & day $^{-1}$ & (1) \\
\hline Grazing preference for $\mathrm{c}$ & oms & & $\rho_{1}$ & 0.35 & 0.7 & isionless & This study \\
\hline Grazing preference for & rozoop & ton & $\rho_{2}$ & 0.2 & 0.2 & sionless & (1) \\
\hline Grazing preference for & & & $\rho_{3}$ & 0.1 & 0.1 & dimensionless & (1) \\
\hline Grazing preference for $\mathrm{c}$ & colitho & rids & $\rho_{4}$ & 0.35 & N/A & sionless & This study \\
\hline PON remineralization ra & & & $\gamma_{7}$ & 0.01 & 0.01 & day $^{-1}$ & This study \\
\hline $\mathrm{bSiO}_{2}$ dissolution rate & & & $\gamma_{4}$ & 0.01 & 0.01 & day $^{-1}$ & This study \\
\hline PIC dissolution rate & & & $\gamma_{8}$ & 0.005 & N/A & day $^{-1}$ & This study \\
\hline PON sinking speed & & & $W_{2}$ & 10.0 & 10.0 & $\mathrm{~m} \mathrm{day}^{-1}$ & (1) \\
\hline $\mathrm{bSiO}_{2}$ sinking speed & & & $W_{4}$ & 20.0 & 20.0 & $\mathrm{~m} \mathrm{day}^{-1}$ & This study \\
\hline PIC sinking speed & & & $W_{5}$ & 20.0 & N/A & $\mathrm{m} \mathrm{day}^{-1}$ & This study \\
\hline Diatom Si:N uptake rati & & & $\mathrm{R}_{\mathrm{SiN}}$ & 1.5 & 1.5 & $\operatorname{molSi}(\operatorname{molN})^{-1}$ & (2) \\
\hline Nitrification rate & & & $\gamma_{5}$ & 0.025 & 0.025 & day $^{-1}$ & (2) \\
\hline Ratio of PIC to organic & bon in & colithophorids & $\varepsilon$ & 1.0 & N/A & $\operatorname{molC}(\mathrm{olC})^{-1}$ & (3) \\
\hline Ratio of carbon to nitrog & in phyto & lankton & $\mathrm{R}_{\mathrm{CN}}$ & 6.625 & 6.625 & $\operatorname{molC}(\operatorname{molN})^{-1}$ & (1) \\
\hline
\end{tabular}

4 Sources noted here are: (1) Chai et al. (2002); (2) Jiang et al. (2003); (3) Fujii et al. (2002). 
Table 2. Vertically-averaged plankton biomass in the euphotic zone (up to $120 \mathrm{~m}$ ) in (1) calcification 2 model and (2) no-calcification model simulations. Composition ratio of each phytoplankton species to 3 total phytoplankton is shown in percentage term in parentheses.

4

\begin{tabular}{|c|c|c|c|c|c|}
\hline & $\begin{array}{c}\text { Picoplankton } \\
\text { (P1) } \\
{\left[\begin{array}{l}\text { mmolN m-3 } \\
\text { moln }\end{array}\right.}\end{array}$ & $\begin{array}{l}\text { Diatoms (P2) } \\
{\left[\text { mmolN m}^{-3}\right]}\end{array}$ & $\begin{array}{l}\text { Coccolithophorids } \\
\text { (P3) }\left[\mathrm{mmolN} \mathrm{m}^{-3}\right]\end{array}$ & 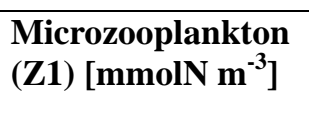 & $\begin{array}{l}\text { Mesozooplankton } \\
\text { (Z2) }\left[\mathrm{mmolN} \mathrm{m}^{-3}\right]\end{array}$ \\
\hline (1) & $0.15(63 \%)$ & $0.06(24 \%)$ & $0.03(13 \%)$ & 0.13 & 0.28 \\
\hline (2) & $0.17(77 \%)$ & $0.05(23 \%)$ & N/A & 0.14 & 0.31 \\
\hline
\end{tabular}


1 Table 3. Model results in the surface water in (I) calcification model simulation and (II) no-calcification 2 model simulations.

\begin{tabular}{|c|c|c|}
\hline State variable & (I) & (II) \\
\hline Picoplankton [mmolN m $\left.{ }^{-3}\right]$ & 0.23 & 0.36 \\
\hline Diatoms $\left[\mathrm{mmolN} \mathrm{m} \mathrm{m}^{-3}\right]$ & 0.13 & 0.06 \\
\hline Coccolithophorids [mmolN m${ }^{-3}$ ] & 0.06 & N/A \\
\hline Total phytoplankton $\left[\mathrm{mmolN} \mathrm{m}^{-3}\right]$ & 0.43 & 0.42 \\
\hline Microzooplankton $\left[\mathrm{mmolN} \mathrm{m} \mathrm{m}^{-3}\right]$ & 0.35 & 0.38 \\
\hline Mesozooplankton [mmolN m $\left.{ }^{-3}\right]$ & 0.65 & 0.89 \\
\hline Total zooplankton [mmolN m$\left.{ }^{-3}\right]$ & 0.99 & 1.27 \\
\hline $\mathrm{NO}_{3}\left[\mathrm{mmolN} \mathrm{m}{ }^{-3}\right]$ & 6.08 & 3.56 \\
\hline $\mathrm{NH}_{4}\left[\mathrm{mmolN} \mathrm{m}{ }^{-3}\right]$ & 0.14 & 0.10 \\
\hline $\mathrm{Si}(\mathrm{OH})_{4}\left[\mathrm{mmolSi} \mathrm{m}^{-3}\right]$ & 3.08 & 5.30 \\
\hline TAlk $\left[\mathrm{mmol} \mathrm{m}^{-3}\right]$ & 2360.9 & 2383.7 \\
\hline $\mathrm{TCO}_{2}\left[\mathrm{mmolC} \mathrm{m}^{-3}\right]$ & 2045.9 & 2034.5 \\
\hline $\mathrm{pCO}_{2 \text { sea }}[\mu \mathrm{atm}]$ & 401.0 & 353.5 \\
\hline Picoplankton specific growth rate $\left[\right.$ day $\left.^{-1}\right]$ & 1.01 & 0.97 \\
\hline Diatom specific growth rate $\left[\mathrm{day}^{-1}\right]$ & 0.45 & 0.55 \\
\hline Coccolithophorid specific growth rate $\left[\right.$ day $\left.^{-1}\right]$ & 0.24 & N/A \\
\hline Specific grazing rate on picoplankton by microzooplankton $\left[\right.$ day $\left.^{-1}\right]$ & 0.95 & 0.92 \\
\hline Specific grazing rate on diatoms by mesozooplankton [ day $\left.^{-1}\right]$ & 0.23 & 0.30 \\
\hline Specific grazing rate on coccolithophorids by mesozooplankton $\left[\right.$ day $\left.^{-1}\right]$. & 0.10 & N/A \\
\hline Specific predation rate on microzooplankton by mesozooplankton $\left[\right.$ day $\left.^{-1}\right]$ & 0.32 & 0.51 \\
\hline Specific grazing rate on PON by mesozooplankton $\quad\left[\right.$ day $\left.^{-1}\right]$ & 0.02 & 0.04 \\
\hline
\end{tabular}


1 Table 4. Comparison of export fluxes and ratios at the bottom of euphotic zone (120m depth).

2

\begin{tabular}{|c|c|c|c|c|c|c|c|}
\hline Experiment & $\begin{array}{l}\text { PON } \\
{[\mathrm{mmolN}} \\
\left.\mathrm{m}^{-2} \text { day }^{-1}\right]\end{array}$ & $\begin{array}{l}\text { POC } \\
{\left[\mathrm{mmolC}^{-2} \text { day }^{-1}\right]} \\
\mathrm{m}^{-2}\end{array}$ & $\begin{array}{l}\mathrm{bSiO}_{2} \\
{\left[\mathrm{mmolSi}^{-2} \mathrm{day}^{-1}\right]} \\
\mathrm{m}^{-1}\end{array}$ & $\begin{array}{l}\text { PIC } \\
{\left[\mathrm{mmolC}^{-2} \text { day }^{-1}\right]} \\
\mathrm{m}^{-2}\end{array}$ & $\begin{array}{l}\mathrm{bSiO}_{2}: \mathrm{PON} \\
\text { ratio }\end{array}$ & $\begin{array}{l}\text { PIC:POC } \\
\text { ratio }\end{array}$ & Source \\
\hline $\begin{array}{l}\text { Survey I } \\
\text { (TT007) }\end{array}$ & $0.38-0.95$ & $0.6-6.3$ & $0.05-0.1$ & & $0.29-0.34$ & & $\begin{array}{l}\text { (1),(2), } \\
\text { (3),(4) }\end{array}$ \\
\hline Time series I (TT008) & & $1.9-5$ & & & & & $(5),(6)$ \\
\hline $\begin{array}{r}\text { Survey II } \\
\text { (TT011) }\end{array}$ & $0.6-4.65$ & $1.5-19.5$ & $0.4-3.9$ & & $0.79-1.25$ & & $\begin{array}{l}\text { (1),(2), } \\
\text { (3),(4) }\end{array}$ \\
\hline Time series II (TT012) & & 2.4 & & & & & (6) \\
\hline FLUPAC & $2.90 \pm 0.65$ & $17.0 \pm 2.5$ & & $2.3 \pm 0.3$ & $0.10-0.23$ & & $\begin{array}{l}\text { (7), (8), } \\
\text { (3),(4) }\end{array}$ \\
\hline OLIPAC & 0.68 & 7.1 & & & & & $\begin{array}{r}\text { (9), (3), } \\
\text { (4) }\end{array}$ \\
\hline Zonal Flux & & & & & $0.14-0.45$ & & (3) \\
\hline EBENE & & $9-20$ & 2.6 & & & & $(10),(11)$ \\
\hline Model & $1.36-1.39$ & $3.8-5.4$ & & & & & $(12),(4)$ \\
\hline Model & 0.76 & 5.01 & 2.36 & N/A & 3.11 & N/A & (13) \\
\hline Model & $0.69-0.98$ & $5.04-7.15$ & $0.35-3.20$ & N/A & $0.36-4.64$ & N/A & (4) \\
\hline $\begin{array}{r}\text { Model } \\
\text { (calcification model } \\
\text { simulation) }\end{array}$ & 0.58 & 3.84 & 1.46 & 0.60 & 2.52 & 0.16 & $\begin{array}{l}\text { This } \\
\text { study }\end{array}$ \\
\hline $\begin{array}{r}\text { Model } \\
\text { (no-calcification } \\
\text { model simulation) }\end{array}$ & 0.51 & 3.38 & 0.74 & N/A & 1.45 & N/A & $\begin{array}{l}\text { This } \\
\text { study }\end{array}$ \\
\hline
\end{tabular}

3

4 Sources noted here are: (1) Luo et al. (1995); (2) Murray et al. (1996); (3) Dunne et al. (1999); (4)

5 Dugdale et al. (2002); (5) Buesseler et al. (1995); (6) Bacon et al. (1996); (7) Le Borgne et al. (1995);

6 (8) Rodier and Le Borgne (1997); (9) Rainbault et al. (1999); (10) Le Borgne et al. (1998); (11)

7 Leynaert et al. (2001); (12) Loukos et al. (1997); (13) Dugdale and Wilkerson (1998). 
Table 5. Sensitivity of surface phytoplankton (P1, P2 and P3 [mmolN m$\left.\left.{ }^{-3}\right]\right)$, zooplankton ( $\mathrm{Z} 1$ and $\left.\mathrm{Z} 2\left[\mathrm{mmolN} \mathrm{m}^{-3}\right]\right)$, nutrients $\left(\mathrm{NO}_{3}\left[\mathrm{mmolN} \mathrm{m}^{-3}\right], \mathrm{NH}_{4}\left[\mathrm{mmolN} \mathrm{m}{ }^{-3}\right]\right.$ and $\left.\mathrm{Si}(\mathrm{OH})_{4}\left[\mathrm{mmolSi} \mathrm{m}^{-3}\right]\right)$, TAlk $\left[\mathrm{mmol} \mathrm{m}{ }^{-3}\right], \mathrm{TCO}_{2}\left[\mathrm{mmolC} \mathrm{m}^{-3}\right]$ and $\mathrm{pCO}_{2 \mathrm{sea}}[\mu \mathrm{atm}]$ and of export PON [mmolN m${ }^{-2}$ day $^{-1}$ ], $\mathrm{bSiO}_{2}\left[\mathrm{mmolSi} \mathrm{m} \mathrm{m}^{-2}\right.$ day $^{-1}$ ] and PIC [mmolC m $\mathrm{m}^{-2}$ day $^{-1}$ ] fluxes, to biogeochemical parameters in calcification model. Values in parentheses denote model results in the standard experiment. The other values mean difference by changing each parameter value from 0.5 to 1.5 times the standard parameter value. The values in bold letters are those that exceed $100 \%$ of each model compartment concentration $\left(10 \%\right.$ of those for Talk, $\mathrm{TCO}_{2}$, and $\left.\mathrm{pCO}_{2 \text { sea }}\right)$. The parameters in bold letters strongly affect the model results and are described in Section 4.1.

\begin{tabular}{|c|c|c|c|c|c|c|c|c|c|c|c|c|c|c|}
\hline Parameter & $\begin{array}{l}\text { P1 } \\
(0.23)\end{array}$ & $\begin{array}{l}\text { P2 } \\
(0.13)\end{array}$ & $\begin{array}{l}\text { P3 } \\
(0.06) \\
\end{array}$ & $\begin{array}{l}\mathrm{Z1} \\
(0.35) \\
\end{array}$ & $\begin{array}{l}\mathrm{Z2} \\
(0.65) \\
\end{array}$ & $\begin{array}{l}\mathrm{NO}_{3} \\
(6.08) \\
\end{array}$ & $\begin{array}{l}\mathrm{NH}_{4} \\
(0.14) \\
\end{array}$ & $\begin{array}{l}\mathrm{Si}(\mathrm{OH})_{4} \\
(3.08)\end{array}$ & $\begin{array}{l}\text { TAlk } \\
(2360.9) \\
\end{array}$ & $\begin{array}{l}\mathrm{TCO}_{2} \\
(2045.9) \\
\end{array}$ & $\begin{array}{l}\mathrm{pCO}_{2 \text { sea }} \\
(401.02)\end{array}$ & $\begin{array}{l}\text { PON } \\
(0.58) \\
\end{array}$ & $\begin{array}{l}\mathrm{bSiO}_{2} \\
(1.36)\end{array}$ & $\begin{array}{l}\text { PIC } \\
(0.60)\end{array}$ \\
\hline$\alpha$ & 0.24 & 0.08 & 0.08 & 0.17 & 0.75 & 7.84 & 0.08 & 0.53 & 21.39 & 80.91 & 183.84 & 0.19 & 0.16 & 0.46 \\
\hline $\boldsymbol{\mu} \mathbf{1}_{\max }$ & 0.20 & 0.08 & 0.08 & 0.21 & 0.66 & 6.49 & 0.08 & 1.90 & 33.12 & 52.64 & 147.05 & 0.03 & 0.59 & 0.84 \\
\hline$\Psi$ & 0.10 & 0.03 & 0.02 & 0.10 & 0.41 & 4.78 & 0.03 & 0.72 & 9.55 & 56.89 & 86.66 & 0.13 & 0.23 & 0.41 \\
\hline$K_{\mathrm{NO} 3}$ & 0.03 & 0.01 & 0.01 & 0.02 & 0.08 & 0.75 & 0 & 0.23 & 3.83 & 5.83 & 16.53 & 0 & 0.07 & 0.1 \\
\hline$K_{\mathrm{NH} 4}$ & 0.17 & 0.05 & 0.04 & 0.10 & 0.50 & 5.53 & 0.10 & 1.50 & 18.69 & 47.19 & 108.01 & 0.05 & 0.48 & 0.42 \\
\hline$\mu 2_{\max }$ & 0.09 & 0.09 & 0.02 & 0.01 & 0.15 & 1.31 & 0.03 & 3.22 & 6.92 & 10.22 & 26.92 & 0.04 & 0.97 & 0.19 \\
\hline$K_{\mathrm{Si}(\mathrm{OH}) 4}$ & 0.02 & 0.04 & 0.00 & 0.01 & 0.01 & 0.32 & 0.01 & 2.03 & 0.84 & 1.33 & 3.83 & 0.05 & 0.63 & 0.02 \\
\hline$K_{\mathrm{S} 2 \_\mathrm{NH} 4}$ & 0.01 & 0.01 & 0.01 & 0.01 & 0.02 & 0.16 & 0.04 & 0.38 & 5.20 & 1.53 & 5.00 & 0.02 & 0.12 & 0.16 \\
\hline$W_{1}$ & 0.00 & 0.02 & 0.00 & 0.00 & 0.01 & 0.02 & 0.00 & 0.15 & 0.13 & 0.24 & 0.65 & 0.03 & 0.03 & 0.01 \\
\hline $\boldsymbol{\mu} \mathbf{3}_{\max }$ & 0.15 & 0.06 & 0.11 & 0.02 & 0.32 & 3.18 & 0.04 & 1.44 & 46.51 & 14.33 & 67.20 & 0.09 & 0.45 & 1.37 \\
\hline$K_{\mathrm{S} 3 \_\mathrm{NO} 3}$ & 0.02 & 0.00 & 0.01 & 0.00 & 0.03 & 0.22 & 0.01 & 0.15 & 5.52 & 0.92 & 6.62 & 0.01 & 0.05 & 0.16 \\
\hline$K_{\mathrm{S} 3 \_\mathrm{NH} 4}$ & 0.06 & 0.02 & 0.07 & 0.03 & 0.11 & 0.71 & 0.01 & 0.57 & 35.24 & 15.30 & 26.28 & 0.09 & 0.18 & 1.08 \\
\hline$W_{3}$ & 0.02 & 0.01 & 0.02 & 0.00 & 0.03 & 0.29 & 0.01 & 0.17 & 4.55 & 0.25 & 7.00 & 0.01 & 0.06 & 0.18 \\
\hline$G 1_{\max }$ & 2.04 & 0.15 & 0.11 & 0.16 & 0.70 & 8.20 & 0.16 & 3.84 & 45.39 & 55.90 & 160.23 & 0.34 & 1.37 & 1.14 \\
\hline$K 1_{\text {gr }}$ & 0.43 & 0.09 & 0.11 & 0.22 & 0.72 & 7.62 & 0.09 & 2.54 & 43.93 & 58.95 & 174.41 & 0.04 & 0.81 & 1.13 \\
\hline $\mathrm{reg}_{1}$ & 0.21 & 0.03 & 0.04 & 0.08 & 0.29 & 2.79 & 0.01 & 1.01 & 17.43 & 46.01 & 112.43 & 0.02 & 0.33 & 0.46 \\
\hline$G 2_{\text {max }}$ & 1.02 & 0.45 & 1.12 & 0.21 & 0.71 & 7.23 & 0.15 & 5.95 & 237.68 & 148.84 & 137.18 & 1.74 & 1.75 & 7.25 \\
\hline$K 2_{\mathrm{gr}}$ & 1.19 & 0.23 & 0.22 & 0.31 & 0.92 & 7.15 & 0.85 & 5.75 & 72.74 & 36.60 & 138.33 & 0.76 & 1.82 & 2.04 \\
\hline$\gamma_{3}$ & 0.02 & 0.02 & 0.00 & 0.01 & 0.02 & 0.19 & 0.01 & 0.57 & 1.21 & 2.62 & 6.66 & 0.03 & 0.16 & 0.04 \\
\hline$\gamma_{6}$ & 0.05 & 0.02 & 0.05 & 0.02 & 0.12 & 0.93 & 0.01 & 0.53 & 15.21 & 2.43 & 25.48 & 0.01 & 0.17 & 0.42 \\
\hline$\gamma_{2}$ & 0.48 & 0.12 & 0.09 & 0.06 & 1.01 & 6.13 & 0.09 & 3.57 & 36.12 & 55.47 & 135.07 & 0.15 & 1.10 & 0.92 \\
\hline $\mathrm{reg}_{2}$ & 0.51 & 0.23 & 0.26 & 0.18 & 0.77 & 7.51 & 0.15 & 5.08 & 85.02 & 33.55 & 114.90 & 0.59 & 1.56 & 2.42 \\
\hline$\gamma_{7}$ & 0.00 & 0.00 & 0.00 & 0.00 & 0.00 & 1.59 & 0.01 & 0.06 & 1.32 & 0.78 & 0.58 & 0.46 & 0.02 & 0.01 \\
\hline$\gamma_{4}$ & 0.01 & 0.03 & 0.00 & 0.00 & 0.00 & 0.15 & 0.01 & 0.68 & 0.30 & 0.57 & 1.32 & 0.02 & 0.18 & 0.02 \\
\hline$\gamma_{8}$ & 0.00 & 0.00 & 0.00 & 0.00 & 0.00 & 0.00 & 0.00 & 0.00 & 1.00 & 0.64 & 0.30 & 0.00 & 0.00 & 0.14 \\
\hline$W_{2}$ & 0.01 & 0.00 & 0.00 & 0.00 & 0.04 & 1.39 & 0.02 & 0.02 & 0.72 & 1.22 & 3.05 & 0.19 & 0.00 & 0.06 \\
\hline$W_{4}$ & 0.02 & 0.04 & 0.00 & 0.01 & 0.02 & 0.38 & 0.01 & 1.14 & 0.94 & 1.88 & 4.76 & 0.03 & 1.22 & 0.02 \\
\hline$W_{5}$ & 0.00 & 0.00 & 0.00 & 0.00 & 0.00 & 0.00 & 0.00 & 0.00 & 1.28 & 0.83 & 0.40 & 0.00 & 0.00 & 0.48 \\
\hline RSiN & 0.08 & 0.16 & 0.01 & 0.03 & 0.19 & 2.70 & 0.05 & 2.97 & 8.60 & 15.19 & 38.69 & 0.17 & 0.92 & 0.17 \\
\hline$\gamma_{5}$ & 0.00 & 0.00 & 0.00 & 0.00 & 0.00 & 0.01 & 0.02 & 0.02 & 1.78 & 1.21 & 0.53 & 0.00 & 0.01 & 0.05 \\
\hline
\end{tabular}




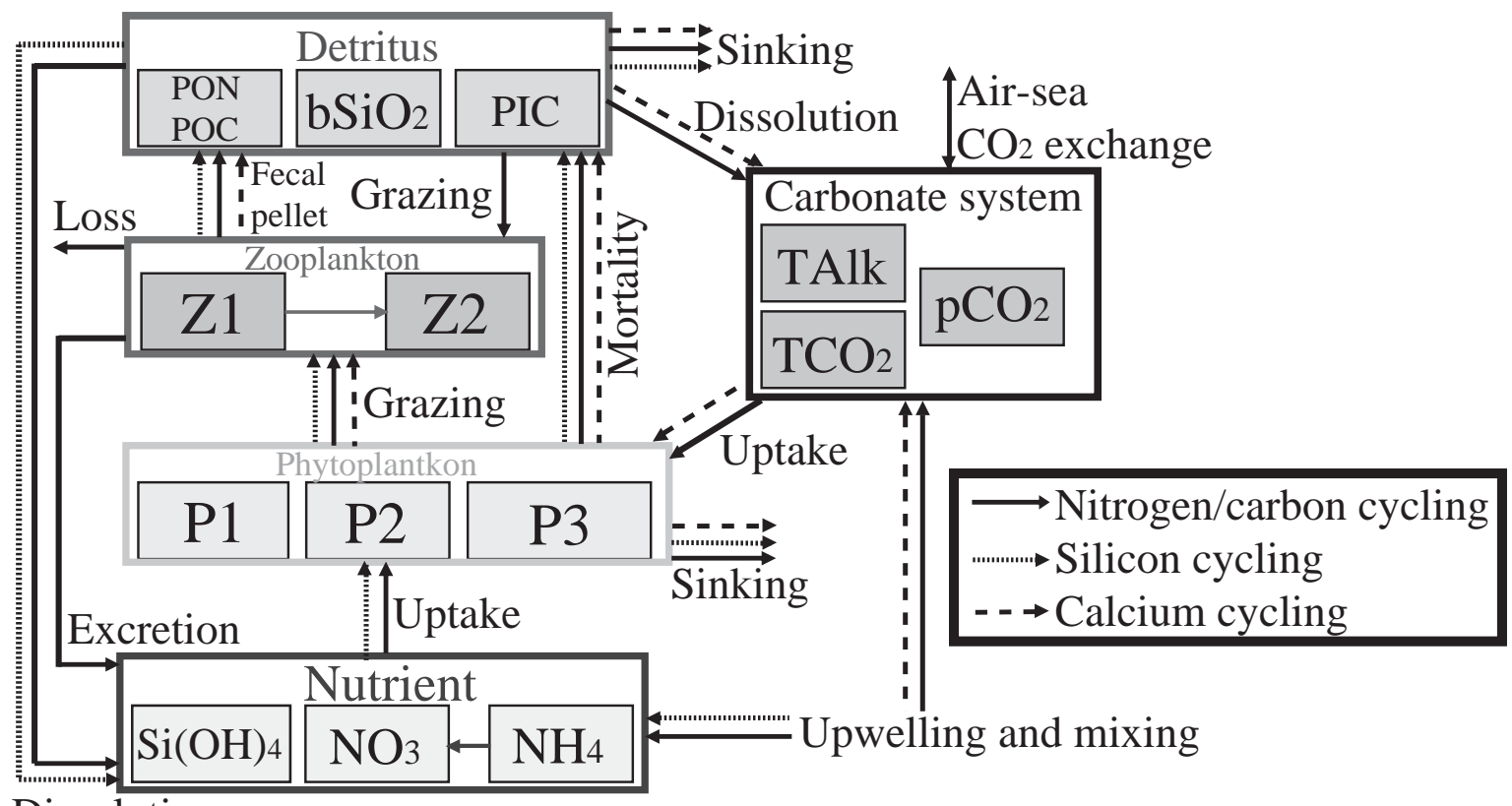

Dissolution

1

2 Fig. 1 The inter-compartmental flow chart of the ecosystem and linkage to physical processes. The

3 flows of nitrogen or carbon are indicated by solid lines, the flows of silicon are indicated by dashed

4 lines, and the flows of calcium are indicated by line-dashed lines. P1: picoplankton, P2: diatoms, P3:

5 coccolithophorids, Z1: microzooplankton, and Z2: mesozooplankton. 


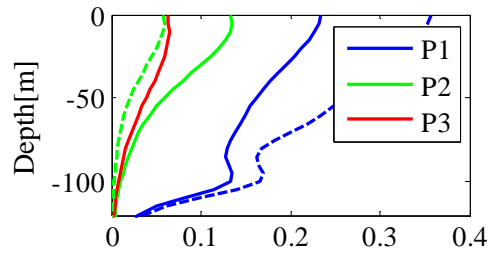

(a) Phytoplantkon $\left[\mathrm{mmolN} \mathrm{m}^{-3}\right.$ ]

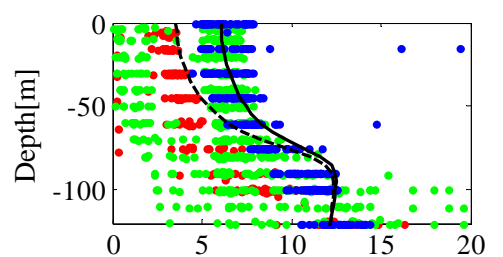

(d) $\mathrm{NO}_{3}\left[\mathrm{mmolN} \mathrm{m}^{-3}\right]$

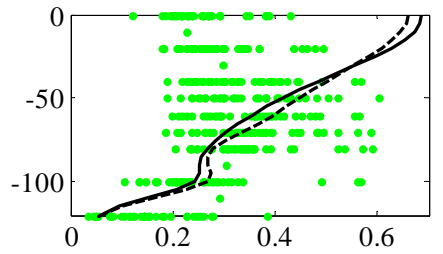

(b) Chlorophyll [mgChl m$\left.{ }^{-3}\right]$

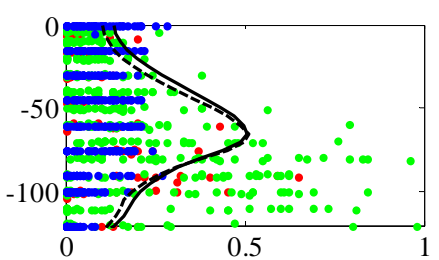

(e) $\mathrm{NH}_{4}\left[\mathrm{mmolN} \mathrm{m}^{-3}\right]$

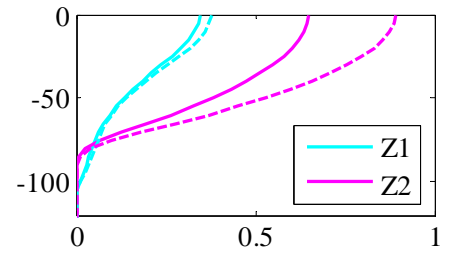

(c) Zooplankton $\left[\mathrm{mmolN} \mathrm{m}{ }^{-3}\right]$

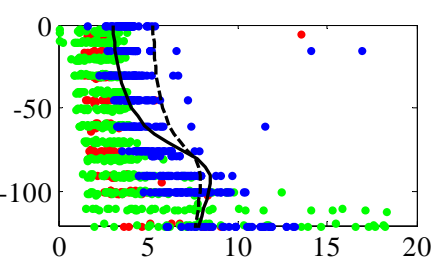

(f) $\mathrm{Si}(\mathrm{OH})_{4}\left[\mathrm{mmolSi} \mathrm{m}^{-3}\right]$

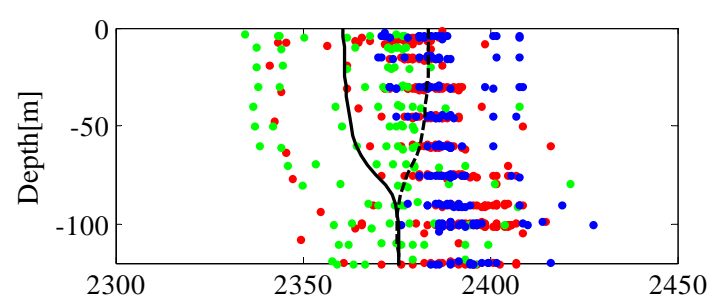

(g) TAlk $\left[\mathrm{mmol} \mathrm{m}^{-3}\right]$

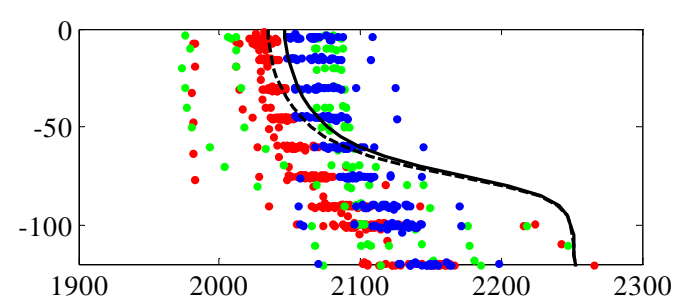

(h) $\mathrm{TCO}_{2}\left[\mathrm{mmolC} \mathrm{m}^{-3}\right]$

Fig. 2. Modeled vertical profiles of (a) phytoplankton biomass $\left[\mathrm{mmolN} \mathrm{m}{ }^{-3}\right]$, (b) chlorophyll $[\mathrm{mgChl}$

$3 \mathrm{~m}^{-3}$, (c) zooplankton biomass $\left[\right.$ mmolN m $\left.\mathrm{m}^{-3}\right]$, (d) $\mathrm{NO}_{3}\left[\mathrm{mmolN} \mathrm{m}^{-3}\right],(\mathrm{e}) \mathrm{NH}_{4}\left[\mathrm{mmolN} \mathrm{m}{ }^{-3}\right],(\mathrm{f}) \mathrm{Si}(\mathrm{OH})_{4}$

$4\left[\mathrm{mmolSi} \mathrm{m}{ }^{-3}\right],(\mathrm{g}) \mathrm{TAlk}\left[\mathrm{mmol} \mathrm{m}^{-3}\right]$, and (h) $\mathrm{TCO}_{2}\left[\mathrm{mmolC} \mathrm{m}^{-3}\right]$. Solid lines: calcification model results.

5 Dotted lines: no-calcification model results. Dots denote the JGOFS EqPac data for TT008 (red dots),

6 TT011 (green dots) and TT012 (blue dots). 
(a)

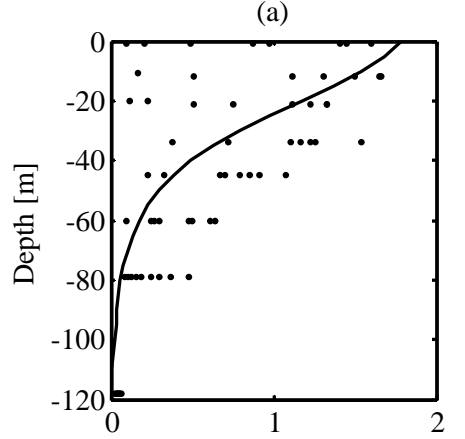

Net comm. prod. [mmolC m ${ }^{-3}$ day $^{-1}$ ]

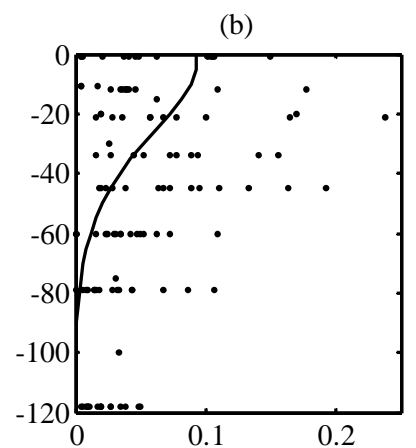

Calcification [mmolC m ${ }^{-3}$ day $^{-1}$ ]

(d)

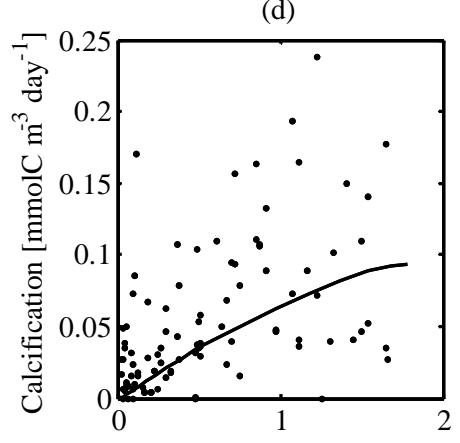

Net comm. prod. [mmolC m ${ }^{-3}$ day $^{-}$

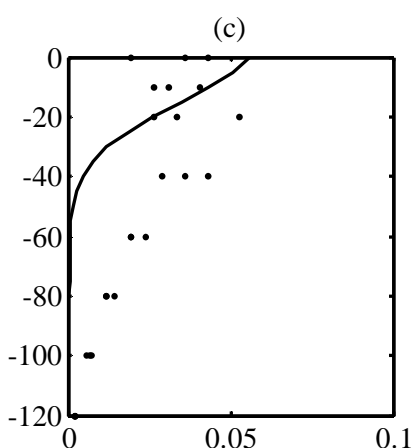

$\mathrm{bSiO}_{2}$ production [mmolSi m${ }^{-3}$ day $^{-1}$ ]

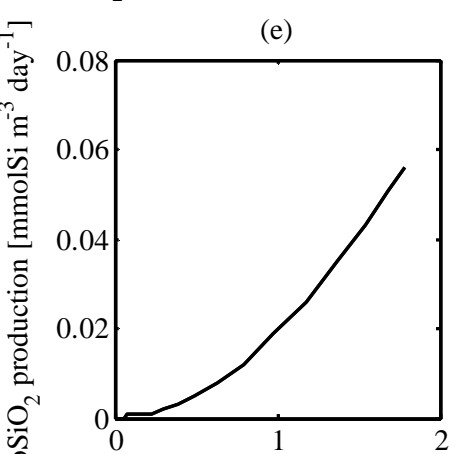

Net comm. prod. [mmolC m ${ }^{-3}$ day $^{-1}$ ]

3 Fig. 3. Modeled (a) vertical profile of net community production [mmolC $\left.\mathrm{m}^{-3} \mathrm{day}^{-1}\right]$, (b) vertical profile

4 of calcification [mmolC m${ }^{-3}$ day $^{-1}$ ], (c) vertical profile of $\mathrm{bSiO}_{2}$ production [mmolSi m${ }^{-3}$ day $^{-1}$ ], (d)

5 calcification [mmolC $\mathrm{m}^{-3} \mathrm{day}^{-1}$ ] vs. net community production $\left[\mathrm{mmolC} \mathrm{m}^{-3}\right.$ day $^{-1}$ ], and (e) $\mathrm{bSiO}_{2}$

6 production [mmolSi $\mathrm{m}^{-3} \mathrm{day}^{-1}$ ] vs. net community production $\left[\mathrm{mmolC} \mathrm{m}^{-3} \mathrm{day}^{-1}\right.$ ] in the euphotic zone.

7 Dots denote the field observation data from EBENE (Leynaert et al., 2001) for $\mathrm{bSiO}_{2}$ production and

8 EqPac Survey II (TT011) (Balch and Kilpatrick, 1996) for the others. 
(a) TAlk $\left[\mathrm{mmol} \mathrm{m}^{-3}\right]$

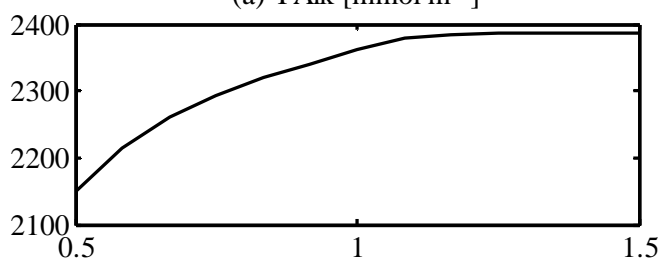

(c) $\mathrm{TCO}_{2}\left[\mathrm{mmolC} \mathrm{m}{ }^{-3}\right]$

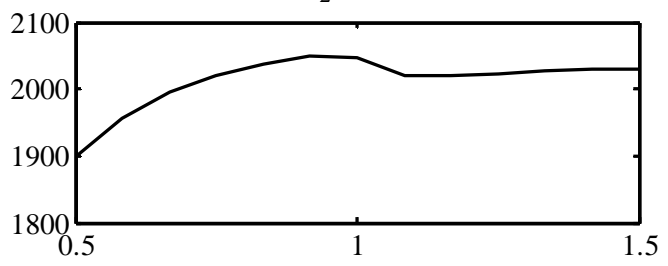

(e) $\mathrm{pCO}_{2 \text { sea }}[\mu \mathrm{atm}]$

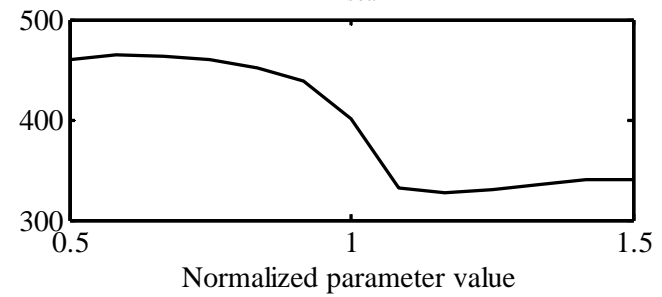

(b) POC export $\left[\mathrm{mmolC} \mathrm{m}{ }^{-2}\right.$ day $\left.^{-1}\right]$

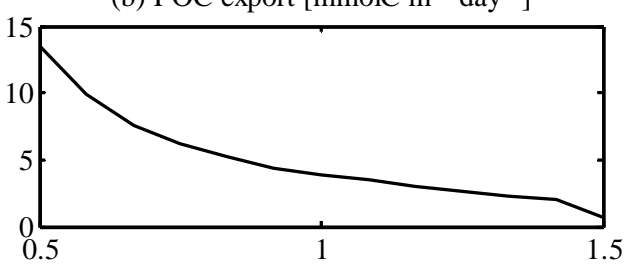

(d) $\mathrm{bSiO}_{2}$ export [mmolSi m ${ }^{-2}$ day $^{-1}$ ]

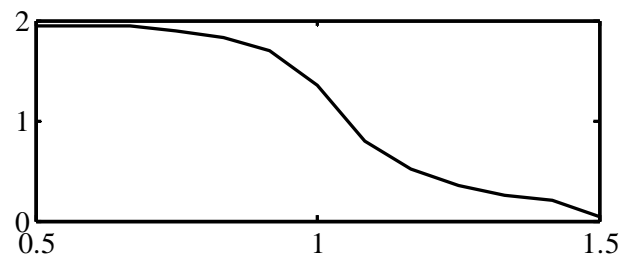

(f) $\mathrm{CaCO}_{3}$ export $\left[\mathrm{mmolC} \mathrm{m} \mathrm{day}^{-1}\right]$

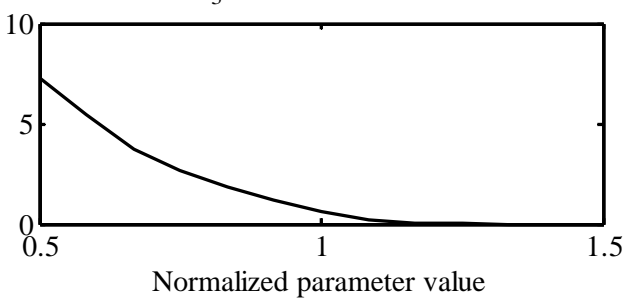

2 Fig. 4. Modeled (a) surface TAlk [mmol kg$\left.{ }^{-3}\right]$, (b) export POC flux $\left[\mathrm{mmolC} \mathrm{m} \mathrm{m}^{-2}\right.$ day $\left.^{-1}\right]$ at $120 \mathrm{~m}$ depth,

3 (c) surface $\mathrm{TCO}_{2}\left[\mathrm{mmolC} \mathrm{m}{ }^{-3}\right]$, (d) export $\mathrm{bSiO}_{2}$ flux $\left[\mathrm{mmolSi} \mathrm{m}{ }^{-2}\right.$ day $\left.^{-1}\right]$ at $120 \mathrm{~m}$ depth, (e) $\mathrm{pCO}_{2 \text { sea }}$

4 [ $\mathrm{\mu atm}]$, and (f) export PIC flux at $120 \mathrm{~m}$ depth $\left[\mathrm{mmolC} \mathrm{m}^{-2}\right.$ day $\left.^{-1}\right]$, obtained by changing the maximum

5 grazing or predation rate by mesozooplankton $\left(G 2_{\max }\right)$ from 0.5 to 1.5 times the standard value. 


$$
{ }^{-\cdots \cdots \cdots \cdots \cdot \cdots} 1_{\max }-----\mathrm{G} 1_{\max }
$$

(b) $\mathrm{TCO}_{2}\left[\mathrm{mmolC} \mathrm{m}^{-3}\right]$

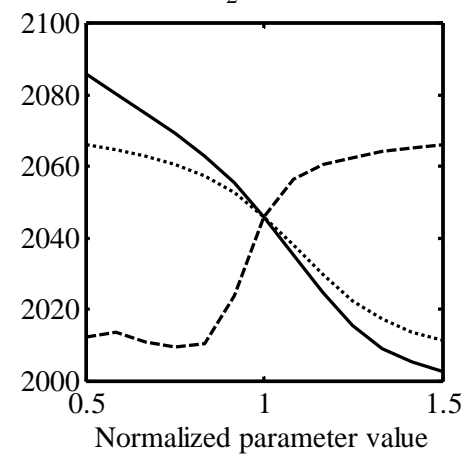

(c) $\mathrm{pCO}_{2 \mathrm{sea}}[\mu \mathrm{atm}]$

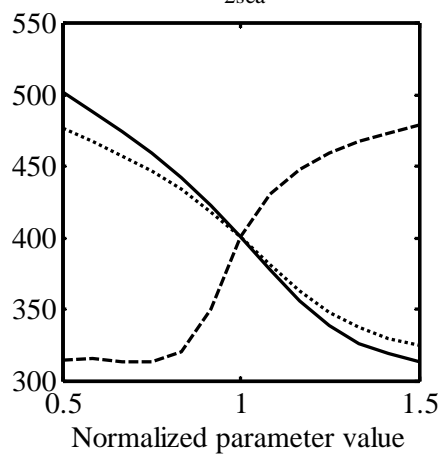

2 Fig. 5. Modeled (a) surface TAlk $\left[\mathrm{mmol} \mathrm{m}^{-3}\right]$, (b) surface $\mathrm{TCO}_{2}\left[\mathrm{mmolC} \mathrm{m}{ }^{-3}\right]$, and (c) $\mathrm{pCO}_{2 s e a}[\mu \mathrm{atm}]$, 3 obtained by changing the initial slope of P-I curve $(\alpha)$, the maximum specific growth rates of 4 picoplankton $\left(\mu 1_{\max }\right)$, and the maximum specific grazing rate on picoplankton by mesozooplankton $5\left(G 1_{\max }\right)$ from 0.5 to 1.5 times the standard value. 
(a) $\mathrm{bSiO}_{2}: \mathrm{PON}$ export ratio

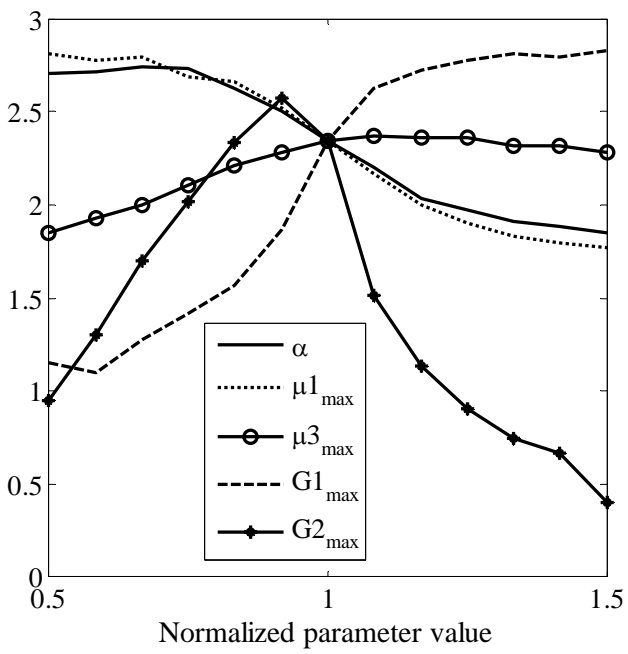

(b) $\mathrm{CaCO}_{3}: \mathrm{POC}$ export ratio

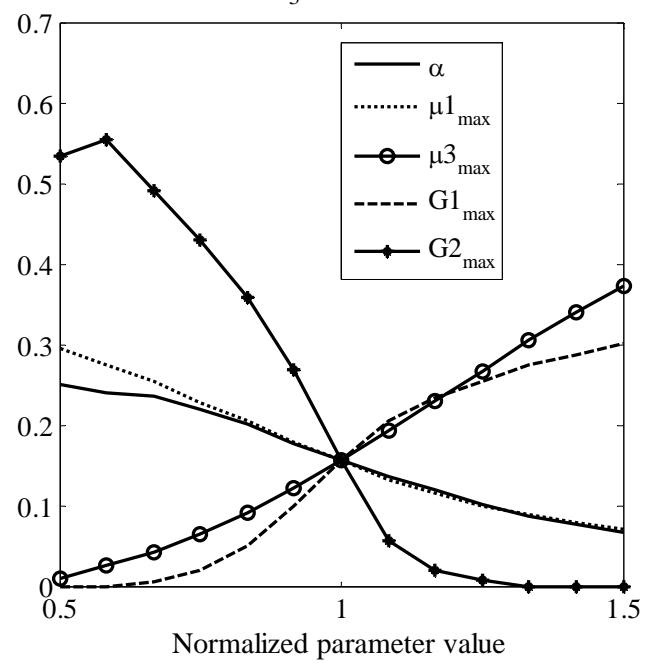

2 Fig. 6. Modeled (a) $\mathrm{bSiO}_{2}: \mathrm{PON}$ export ratio and (b) PIC:POC export ratio (rain ratio) at $120 \mathrm{~m}$ depth,

3 obtained by changing the initial slope of P-I curve $(\alpha)$, the maximum specific growth rates of

4 picoplankton $\left(\mu 1_{\max }\right)$ and coccolithophorids $\left(\mu 3_{\max }\right)$, the maximum specific grazing or predation rates

5 by mesozooplankton $\left(G 1_{\max }\right)$ and mesozooplankton $\left(G 2_{\max }\right)$ from 0.5 to 1.5 times the standard values. 
(a) P1 and P2 [mmolN m $\left.{ }^{-3}\right]$

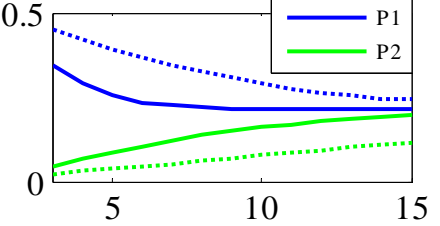

(d) Phytoplankton composition ratio

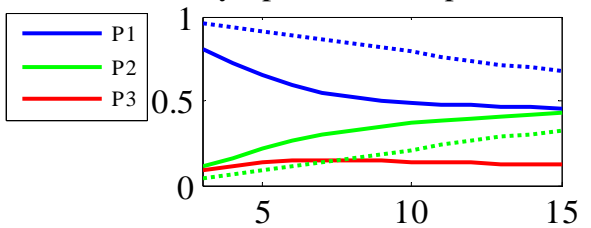

(g) TAlk $\left[\mathrm{mmol} \mathrm{m}^{-3}\right]$

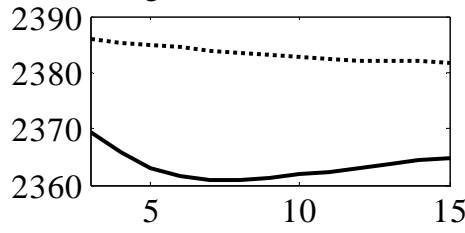

$\mathrm{Si}(\mathrm{OH}) 4$ at $120 \mathrm{~m}\left[\mathrm{mmolSi} \mathrm{m}^{-3}\right]$ (b) P3 [mmolN m $\left.{ }^{-3}\right]$

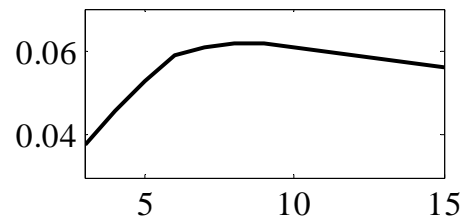

(e) $\mathrm{NO}_{3}\left[\mathrm{mmolN} \mathrm{m}{ }^{-3}\right]$

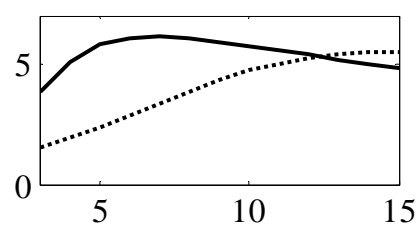

(h) $\mathrm{TCO}_{2}\left[\mathrm{mmolC} \mathrm{m}{ }^{-3}\right]$

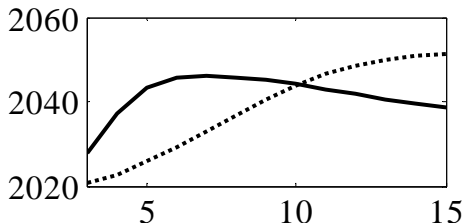

(c) Total phytoplankton $\left[\right.$ mmolN $\left.\mathrm{m}^{-3}\right]$

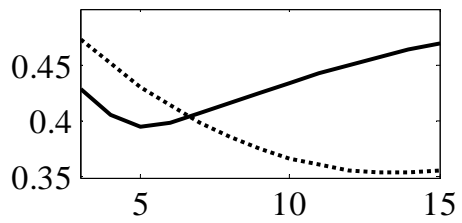

(f) $\mathrm{Si}(\mathrm{OH})_{4}\left[\mathrm{mmolSi} \mathrm{m}^{-3}\right]$

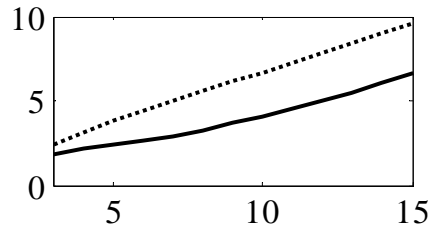

(i) $\mathrm{pCO}_{2 \mathrm{sea}}[\mu \mathrm{atm}]$

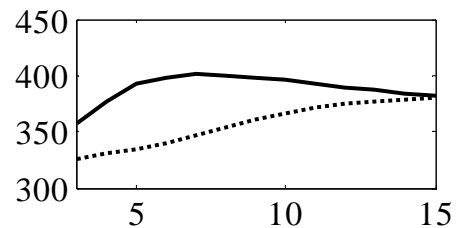

$\mathrm{Si}(\mathrm{OH}) 4$ at $\left.120 \mathrm{~m}_{[\mathrm{mmolSi} \mathrm{m}}^{-3}\right] \quad \mathrm{Si}(\mathrm{OH}) 4$ at $120 \mathrm{~m}_{[\mathrm{mmolSi} \mathrm{m}}^{-3}$ ]

2 Fig. 7 Modeled surface (a) picoplankton (P1; in blue) and diatom (P2; in green) [mmolN m ${ }^{-3}$, (b)

3 coccolithophorids $(\mathrm{P} 3)\left[\mathrm{mmolN} \mathrm{m} \mathrm{m}^{-3}\right]$, (c) total phytoplankton $(\mathrm{P} 1+\mathrm{P} 2+\mathrm{P} 3$ for calcification model

4 simulation and $\mathrm{P} 1+\mathrm{P} 2$ for no-calcification model simulation) $\left[\mathrm{mmolN} \mathrm{m}^{-3}\right]$, (d) phytoplankton

5 composition ratio of picoplankton (in blue), diatoms (in green), and coccolithophorids (in red) to total

6 phytoplankton, (e) $\mathrm{NO}_{3}\left[\mathrm{mmolN} \mathrm{m}^{-3}\right]$, (f) $\mathrm{Si}(\mathrm{OH})_{4}\left[\mathrm{mmolSi} \mathrm{m}{ }^{-3}\right]$, (g) TAlk $\left[\mathrm{mmol} \mathrm{m}^{-3}\right]$, (h) $\mathrm{TCO}_{2}$

$7\left[\mathrm{mmolC} \mathrm{m}^{-3}\right]$, and (i) $\mathrm{pCO}_{2 \text { sea }}[\mu \mathrm{atm}]$, vs. source $\mathrm{Si}(\mathrm{OH})_{4}$ concentration $\left[\mathrm{mmolSi} \mathrm{m}^{-3}\right]$ in Experiment 2.

8 Solid lines: calcification model results. Dotted lines: no-calcification model results. 
(a) Picoplankton (P1)

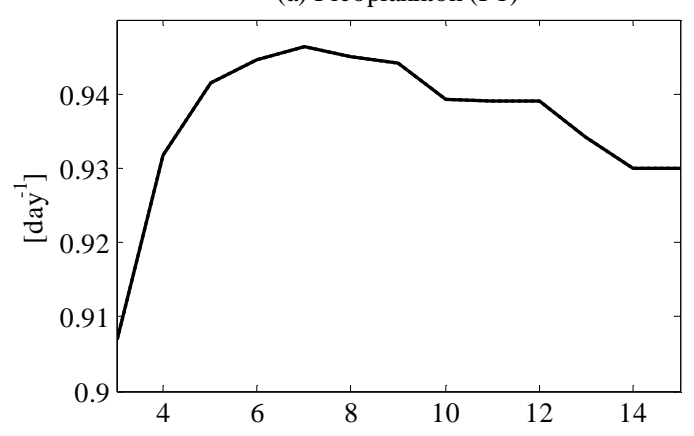

(c) Coccolithophorids (P3)

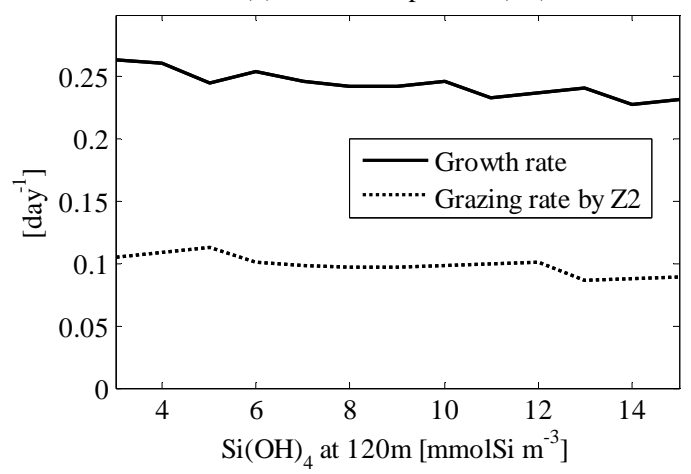

(b) Diatoms (P2)

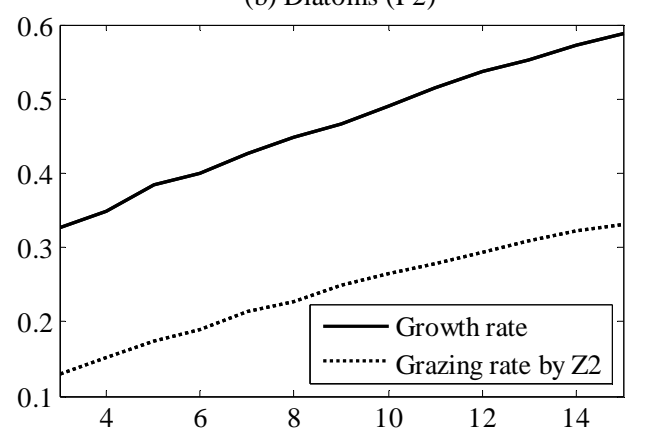

(d) Microzooplankton (Z1)

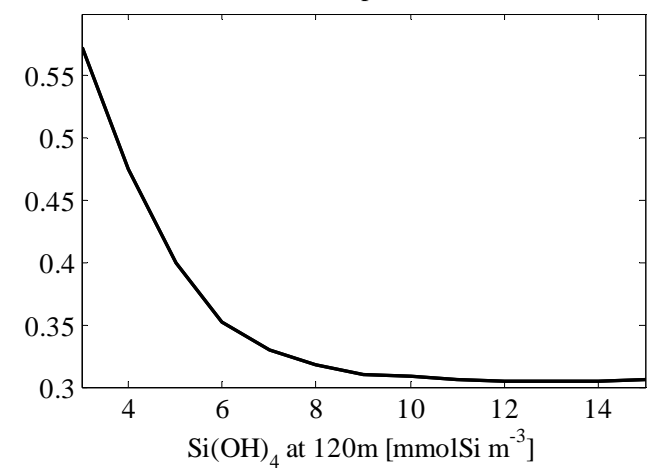

2 Fig. 8. Modeled specific (divided by each biomass) (a) grazing rate on picoplankton (P1) by

3 microzooplankton $(\mathrm{Z} 1)\left[\right.$ day $\left.^{-1}\right],(\mathrm{b})$ diatom (P2) growth rate and grazing rate by mesozooplankton (Z2)

4 day $\left.^{-1}\right],(\mathrm{c})$ coccolithophorid (P3) growth rate and grazing rate by mesozooplankton $\left[\right.$ day $\left.^{-1}\right]$, and (d)

5 predation rate on microzooplankton by mesozooplankton $\left[\mathrm{day}^{-1}\right]$ in the surface water, vs. source

$6 \mathrm{Si}(\mathrm{OH})_{4}$ concentration $\left[\mathrm{mmolSi} \mathrm{m}{ }^{-3}\right]$ in Experiment 2. 

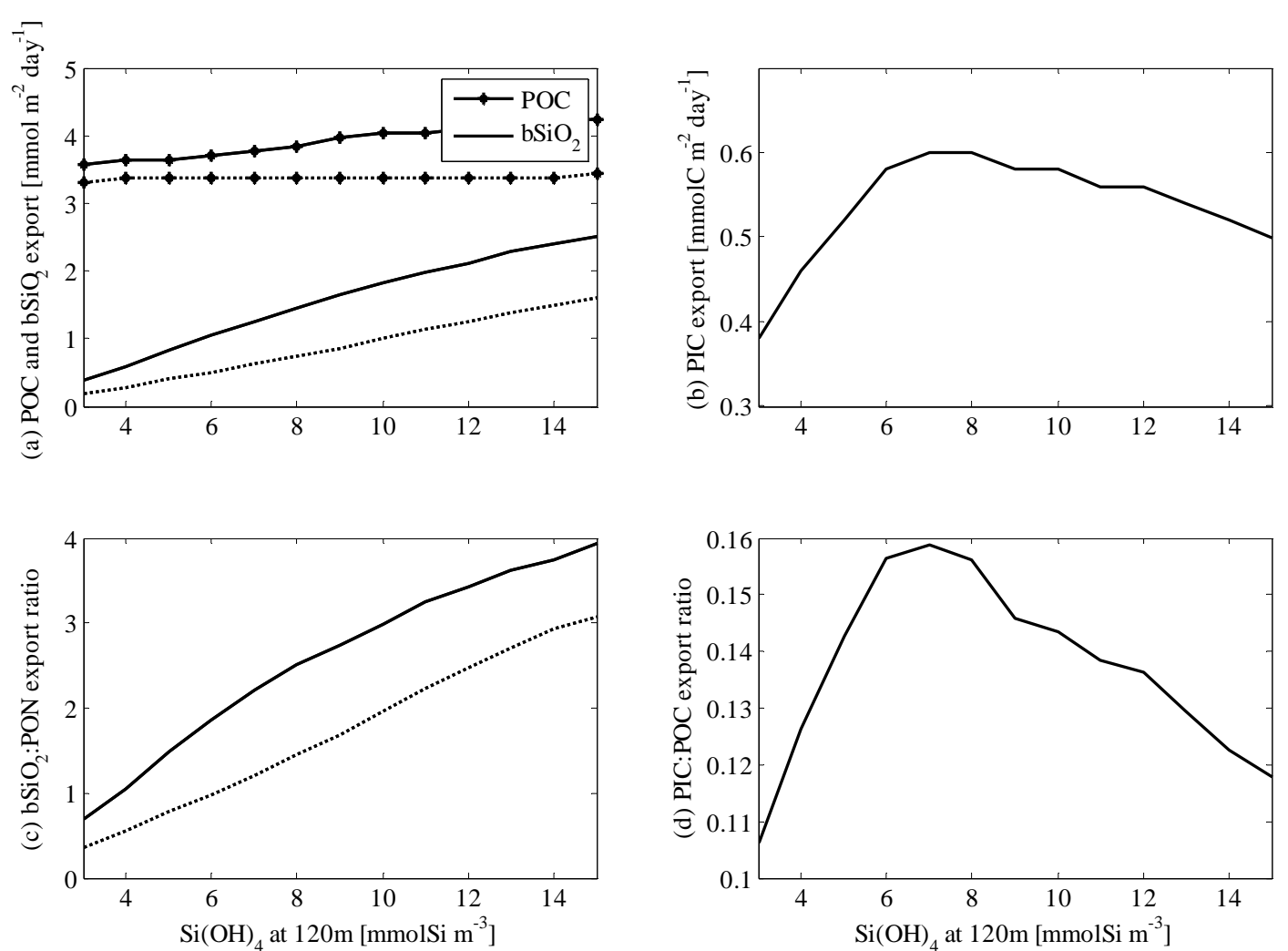

2 Fig. 9. Modeled (a) export flux of POC $\left[\mathrm{mmolC} \mathrm{m}{ }^{-2}\right.$ day $\left.^{-1}\right]$ and $\mathrm{bSiO}_{2}\left[\mathrm{mmolSi} \mathrm{m}^{-2}\right.$ day $\left.^{-1}\right]$, (b) export

3 PIC flux [mmolC m${ }^{-2}$ day $^{-1}$ ], (c) export $\mathrm{bSiO}_{2}: \mathrm{PON}$ ratio, and (d) export PIC:POC ratio (rain ratio) at

$4120 \mathrm{~m}$ depth vs. source $\mathrm{Si}(\mathrm{OH})_{4}$ concentration [mmolSi m${ }^{-3}$ ] in Experiment 2. Solid lines: calcification 5 model results. Dotted lines: no-calcification model results. 

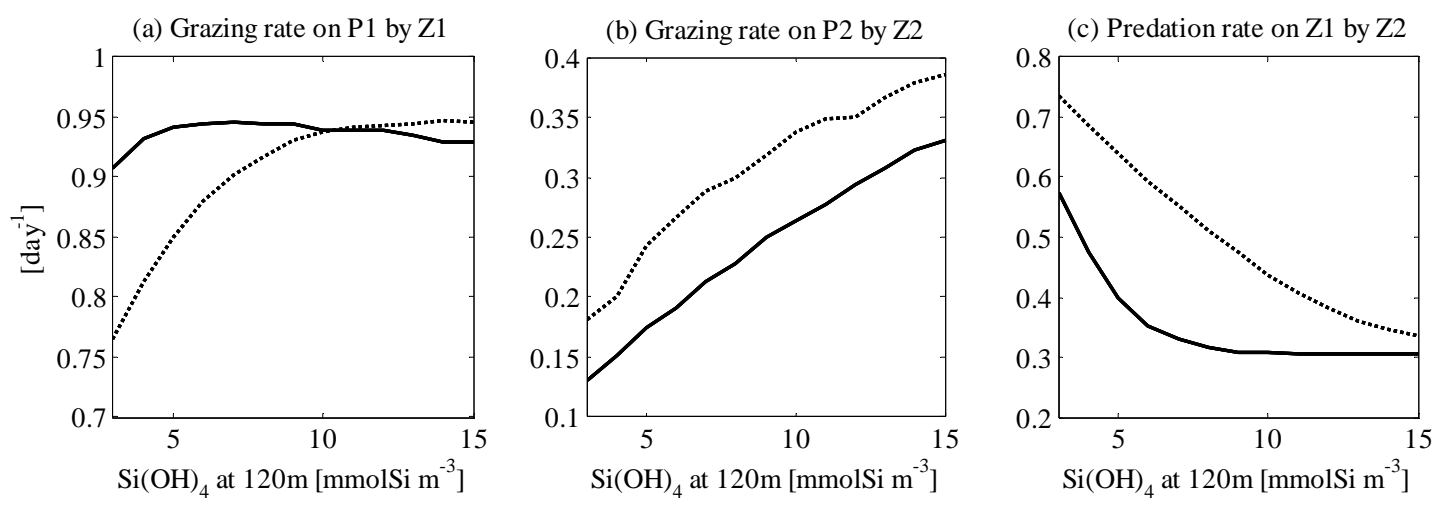

2 Fig. 10. Modeled specific (divided by each biomass) (a) grazing rate on picoplankton (P1) by

3 microzooplankton (Z1) [day ${ }^{-1}$, (b) grazing rate on diatom (P2) by mesozooplankton (Z2) [day ${ }^{-1}$, and

4 (c) predation rate on microzooplankton (Z1) by mesozooplankton (Z2) $\left[\right.$ day $\left.^{-1}\right]$ in the surface water vs.

5 source $\mathrm{Si}(\mathrm{OH})_{4}$ concentration $\left[\mathrm{mmolSi} \mathrm{m}{ }^{-3}\right]$ in Experiment 2. Solid lines: calcification model results.

6 Dotted lines: no-calcification model results. 

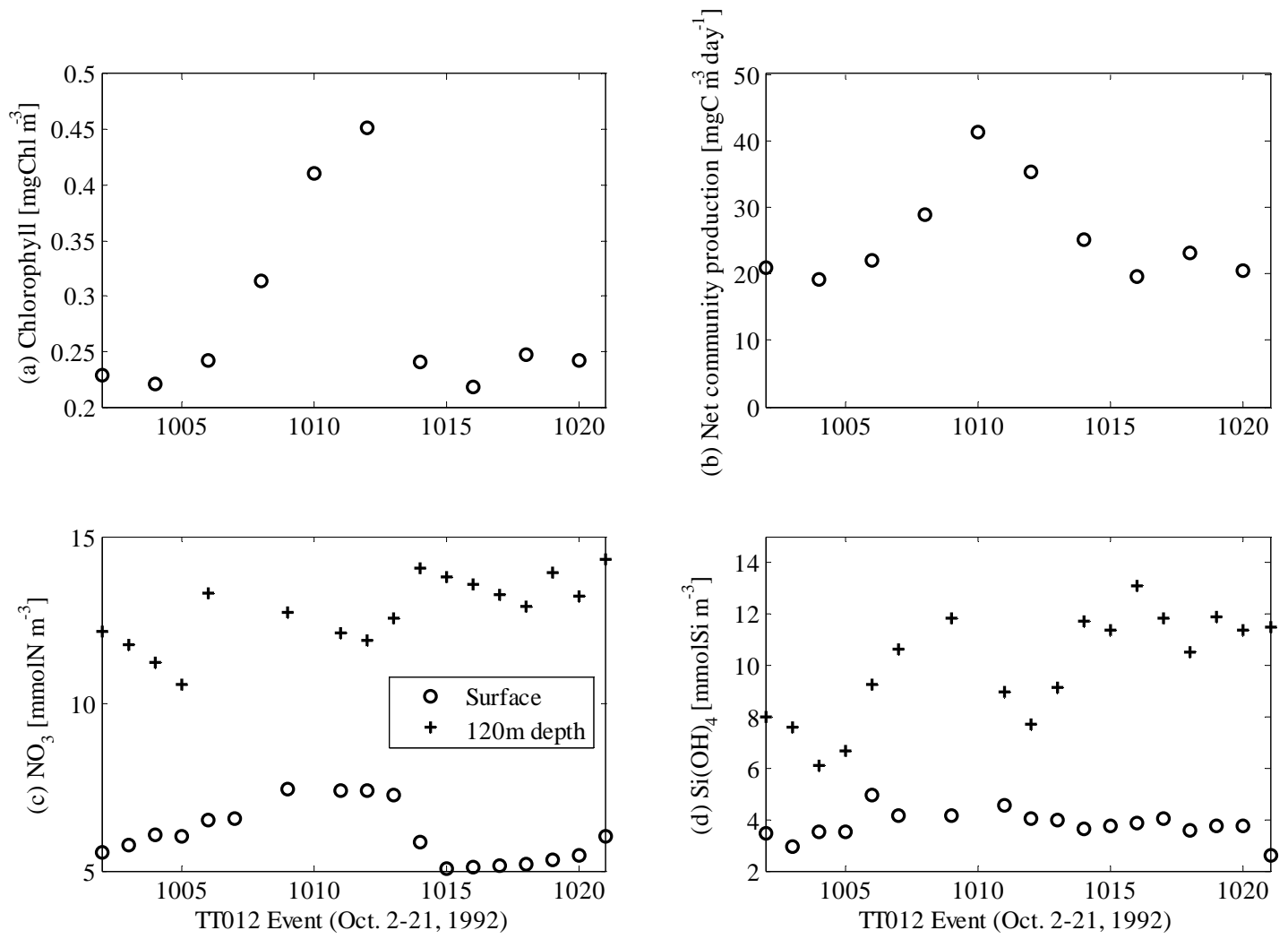

1

2 Fig. 11. (a) chlorophyll $\left[\mathrm{mgChl} \mathrm{m} \mathrm{m}^{-3}\right]$, (b) net community production $\left[\mathrm{mgC} \mathrm{m}^{-3}\right.$ day $\left.^{-1}\right]$, (c) $\mathrm{NO}_{3}[\mathrm{mmolN}$

$3 \mathrm{~m}^{-3}$ ] and (d) $\mathrm{Si}(\mathrm{OH})_{4}\left[\mathrm{mmolSi} \mathrm{m}{ }^{-3}\right]$ at the surface (open dots) or bottom (crosses) of the euphotic zone 4 (120m depth) during the JGOFS EqPac Time series II (TT012) from Oct. 2 to Oct. 21, 1992. 

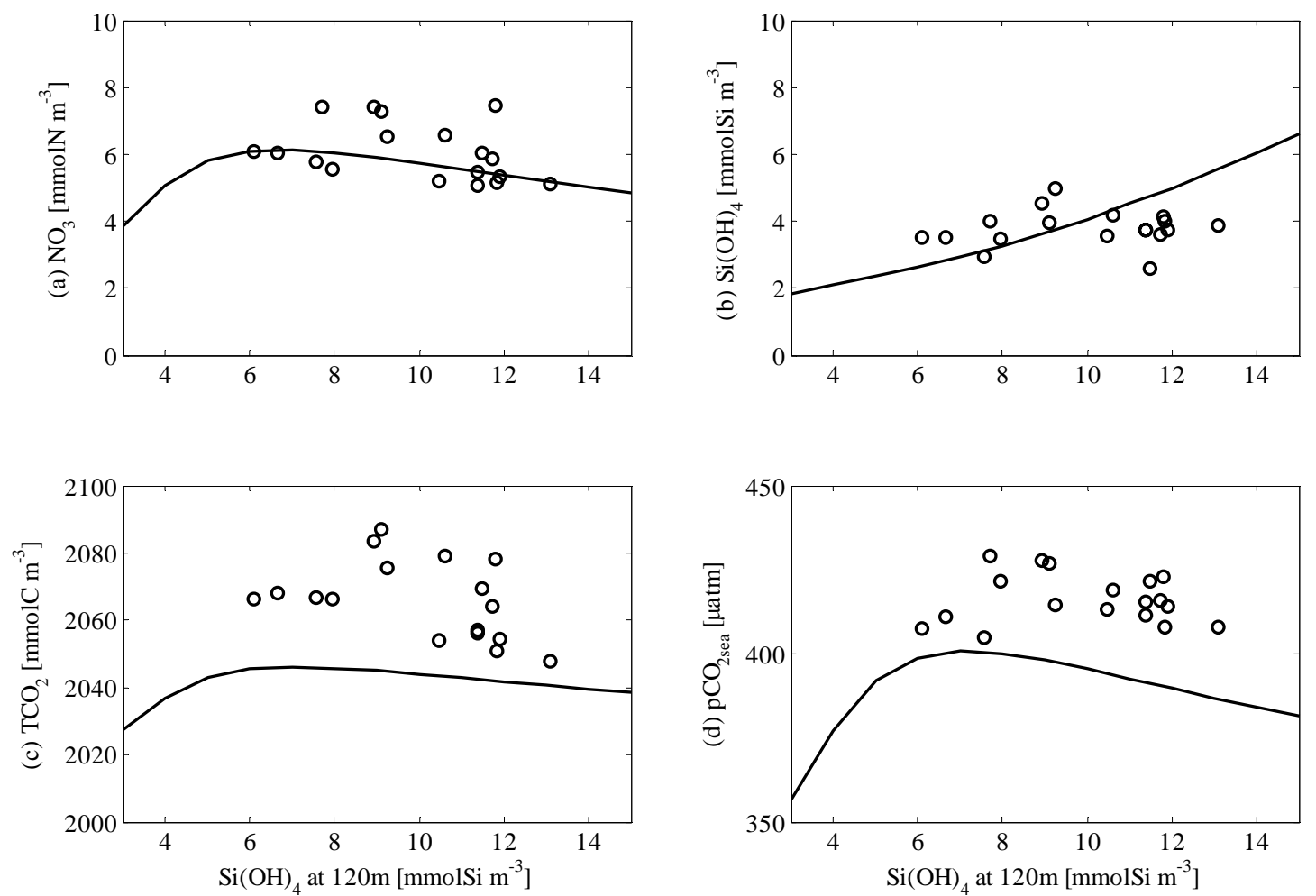

2 Fig. 12. Surface (a) $\mathrm{NO}_{3}\left[\mathrm{mmolN} \mathrm{m}^{-3}\right]$, (b) $\mathrm{Si}(\mathrm{OH})_{4}\left[\mathrm{mmolSi} \mathrm{m} \mathrm{m}^{-3}\right]$, (c) $\mathrm{TCO}_{2}\left[\mathrm{mmolC} \mathrm{m}^{-3}\right]$ and (d) $3 \mathrm{pCO}_{2 \text { sea }}[\mu \mathrm{atm}]$ vs. source $\mathrm{Si}(\mathrm{OH})_{4}$ concentration $\left[\mathrm{mmolSi} \mathrm{m}^{-3}\right]$. Open dots: the JGOFS EqPac Time 4 series II (TT012) data from Oct. 2 to Oct. 21, 1992; Solid lines: calcification model results in 5 Experiment 2. 